\title{
Expression of Multiple Neurotransmitter Receptors by Sympathetic Preganglionic Neurons in vitro
}

\author{
Beverly Clendening ${ }^{\mathrm{a}}$ and Richard I. Hume \\ Department of Biology, University of Michigan, Ann Arbor, Michigan 48109
}

Neurons in the CNS generally receive inputs from multiple afferent sources. These afferent systems seldom all use the same neurotransmitter, so most central neurons are required to express multiple neurotransmitter receptors. This work addresses the issue of how multiple neurotransmitter receptors are regulated on the surface of individual neurons. We made whole-cell voltage-clamp recordings from identified chick sympathetic preganglionic neurons (SPNs) in dissociated cell cultures. The neurons were derived from stage 30-31 (7 d) chick embryos and were studied within the first week in vitro. We found that by 1 week in vitro, most SPNs responded to the application of GABA, glycine, and glutamate. The responses of SPNs to the amino acid neurotransmitters were similar to the responses of other CNS neurons to these 3 substances. SPNs became sensitive to these substances at different times in culture. At $1 \mathrm{~d}$ in vitro, most cells already responded to GABA, and about half of the cells also responded to glycine and kainate. In contrast, responses to NMDA and quisqualate were usually not seen until day 3-4 in vitro. Although there was a general trend for the amplitude of the responses of SPNs to each of the neurotransmitters to increase with time in vitro, there was an immense amount of cell-to-cell variability. By measuring the amplitudes of the responses of a series of SPNs to all 3 transmitters, we were able to test whether a common regulatory mechanism governed the level of responsiveness of SPNs to all 3 amino acid transmitters. We found no correlation between cells in the amplitudes of their responses to the 3 transmitters. Both the differences in time course of appearance of responsiveness and the lack of correlation in the amplitude of responses suggest that the multiple receptors on the surface of SPNs in vitro are independently regulated.

Most of what is known about the regulation of neurotransmitter receptors at the cellular level concerns the regulation of $\mathrm{ACh}$ receptors at the vertebrate neuromuscular junction. Synapses on both peripheral and central neurons differ in several impor-

\footnotetext{
Received Mar. 5, 1990; revised Aug. 1, 1990; accepted Aug. 20, 1990.

We thank Susan Barry, Stephen Easter, Daniel Goldman, and Hylan Moises for helpful comments on the manuscript and Nancy Hall and Mark Zawisa for excellent technical assistance. This research was supported by NIH Grant NS21043 to R.H., Training Grants MH 14279 and HD 07274 to B.C., and National Institute of Mental Health Grant MH09682 to B.C. R.H. was a fellow of the Sloan Foundation during part of this work.

Correspondence should be addressed to Dr. Richard I. Hume.

a Present address: Department of Biology, B-022, University of California at San Diego, La Jolla, CA 92093.

Copyright (C) 1990 Society for Neuroscience $0270-6474 / 90 / 123977-15 \$ 03.00 / 0$
}

tant ways from synapses at the neuromuscular junction. One notable difference is that some peripheral and most central neurons receive inputs from multiple afferent sources. Furthermore, it is typically the case that these afferent systems do not all use the same neurotransmitter. Most neurons, therefore, must express and regulate multiple neurotransmitter receptors. This need to regulate more than 1 receptor type introduces a set of interesting questions concerning the regulation of multiple receptors. Fundamental to these questions is whether multiple receptors are regulated independently or in a coordinate manner. For instance, are the various receptor types first inserted into the membrane at the same time during development, or do different receptors follow different time courses? Electrophysiological studies of dissociated cells in culture provide a good method for studying the regulation of neurotransmitter receptors on individual CNS neurons. Early studies of this type showed that individual neurons in dissociated cell cultures can express multiple receptor types, and that the level of expression of these receptors can vary dramatically from cell to cell (Ransom et al., 1977). The source of the variability in these studies, however, was unclear. Because the cultures studied were heterogeneous, with multiple neuronal types present, the source of this variability might have been due to differences in responsiveness either within or among classes of neurons.

Scveral groups have now developed techniques for studying living neurons of identified cell types in culture (Okun, 1981; Honig and Hume, 1986; O'Brien and Fischbach, 1986a). In the work reported here, we used techniques developed by Honig and Hume (1986) to identify chick sympathetic preganglionic neurons (SPNs) in culture and to study the regulation of multiple neurotransmitter receptors on these identified cells. Mammalian preganglionic neurons in vivo are believed to receive input from intraspinal neurons that release GABA (Graham et al., 1967; Ljungdahl and Hokfelt, 1973; Fagg and Foster, 1983), glycine (Graham et al., 1967; Aprison et al., 1969; Ljungdahl and Hokfelt, 1973; Fagg and Foster, 1983), and glutamate (Graham et al., 1967; Fagg and Foster, 1983). SPNs in mammals also receive descending afferent input from brain-stem raphe cells that release serotonin (Dahlstrom and Fuxe, 1965; Coote and MacLeod, 1974; Gilbey et al., 1981; Loewy and McKellar, 1981) and noradrencrgic inputs from A1 and A5 catecholamine cell groups and from the locus coeruleus (Loewy et al., 1979; Glazer and Ross, 1980; Fleetwood-Walker and Coote, 1981). Considerable evidence suggests that similar pathways are found in birds (Cabot et al., 1982). In this paper, we address 4 issues: (1) To which of these putative neurotransmitters are identified SPNs responsive? (2) What is the time course of appearance of responsiveness to various neurotransmitlers? (3) Is there heterogeneity of expression of receptors in a homogeneous population 
Table 1. Composition of solutions (in mM)

\begin{tabular}{|c|c|c|c|c|c|}
\hline & $\begin{array}{l}\text { Normal } \\
\text { ex- } \\
\text { ternal }\end{array}$ & $\begin{array}{l}\mathrm{Mg}^{2+} \\
\text { free } \\
\text { ex- } \\
\text { ternal }\end{array}$ & $\begin{array}{l}\text { Normal } \\
\text { internal }\end{array}$ & $\begin{array}{l}\text { High- } \\
\mathrm{Cl}^{-} \\
\text {internal }\end{array}$ & $\begin{array}{l}\text { Low- } \\
\mathrm{Cl}^{-} \\
\text {internal }\end{array}$ \\
\hline $\mathrm{NaCl}$ & 132.0 & 140.0 & 0.5 & 1.0 & - \\
\hline $\mathrm{KCl}$ & 5.3 & 5.3 & 72.5 & 135.0 & 10.0 \\
\hline KAspartate & - & - & 65.0 & - & 130.0 \\
\hline $\mathrm{CaCl}_{2}$ & 5.4 & 5.4 & 1.0 & 1.0 & 1.0 \\
\hline $\mathrm{MgCl}_{2}$ & - & - & 2.1 & 2.2 & 2.0 \\
\hline $\mathrm{MgSO}_{4}$ & 1.7 & - & - & - & - \\
\hline $\mathrm{NaHPO}_{4}$ & 1.3 & 1.3 & - & - & - \\
\hline $\mathrm{K}_{2} \mathrm{EGTA}$ & - & - & 11.0 & 11.0 & 11.0 \\
\hline HEPES (pH, 7.4) & 12.0 & 12.0 & - & - & - \\
\hline HEPES (pH, 7.2) & - & - & 10.0 & 10.0 & 10.0 \\
\hline Glucose & 6.3 & 6.3 & 10.0 & 10.0 & 10.0 \\
\hline Phenol red & 0.2 & 0.2 & - & - & - \\
\hline
\end{tabular}

of cells? (4) Are multiple neurotransmitter receptors on single CNS neurons regulated independently or in a coordinate manner? In the paper that follows (Clendening and Hume, 1990), we consider whether receptors are regulated intrinsically or by cell interactions and what mechanisms underlie the regulation of receptors on these CNS neurons.

\section{Materials and Methods}

Cell culture methods. Heterogeneous spinal cord cells, containing fluorescently labeled SPNs and unlabeled non-neuronal cells and interneurons, were obtained by methods developed by Honig and Hume (1986). Briefly, 7-d chick embryos (stage 30-31) were decapitated and eviscerated, and a ventral laminectomy was performed. Sympathetic chain ganglia from $\mathrm{T} 1$ to LS2 were exposed and injected bilaterally with the fluorescent carbocyanine dye, 1,1'-dioctodecyl-3,3,3,3'-tetramethylindocarbocyanine perchlorate (diI; Molecular Probes, Junction City, $\mathrm{OK})$. The dye was dissolved in $100 \%$ ethanol $(2.5 \mathrm{mg} / \mathrm{ml})$. 'T he injected preparations were left for $16-18 \mathrm{hr}$ at $30^{\circ} \mathrm{C}$ in sterile, oxygenated Tyrode's solution to allow for uptake and diffusion of the dye. The medial half of the spinal cord was separated from the lateral half using a sharp tungsten needle. The medial half was then minced and incubated in $0.02 \%$ collagenase (Type IV, Sigma) in $\mathrm{Ca}^{2+}-, \mathrm{Mg}^{2+}$-free Puck's solution for $30 \mathrm{~min}$ at $37^{\circ} \mathrm{C}$. The cells were then removed from the enzyme, resuspended in medium, and triturated. Intact cells were separated from debris using low-speed spins in medium with $4 \%$ BSA. The cells were plated in chick-muscle-conditioned medium and 5\% chick-embryo extract on glass-bottomed well dishes that had been prepared with a substratum of polyornithine $(1 \mathrm{mg} / \mathrm{ml})$ and laminin $(50 \mu \mathrm{g} / \mathrm{ml})$. After $6 \mathrm{hr}$, when cells had adhered to the bottom of the dishes, $1.5-2.0 \mathrm{ml}$ neuron medium was added to each dish. Dished were incubated in a $5 \% \mathrm{CO}_{2}$ incubator at $37^{\circ} \mathrm{C}$.

The neuron medium contained F12 (Gibco), 2\% heat-inactivated horse serum, $2 \mu \mathrm{g} / \mathrm{ml}$ glutamine, $8 \mu \mathrm{g} / \mathrm{ml}$ insulin, $40 \mu \mathrm{g} / \mathrm{ml}$ conalbumin, $12 \mu \mathrm{g} / \mathrm{ml}$ ascorbic acid, $50 \mathrm{U} / \mathrm{ml}$ penicillin, $50 \mu \mathrm{g} / \mathrm{ml}$ streptomycin, and $50 \mathrm{ng} / \mathrm{ml} 7 \mathrm{~S}$ nerve growth factor. Eagle's minimum essential medium (MEM) was substituted for F12 to make MEM-based neuron medium, and glutamine was not added.

Recording methods. Whole-cell recordings were made as described by Hamill et al. (1981) using a List EPC 5 patch-clamp amplifier. Conventional intracellular recordings were made with glass microelectrodes filled with $300 \mathrm{~mm} \mathrm{KCl}$ using a Getting Model 5A microelectrode amplifier. Intracellular recordings were made using a single electrode with a balanced bridge for both measuring potential and passing current. Data were digitized on line by a 12 -bit A/D converter and stored digitally on disk.

Culture dishes were mounted on the stage of an inverted microscope (Zeiss IM 35) and viewed with phase-contrast optics. To identify SPNs labeled with diI, cells were viewed briefly through a standard rhodamine filter set. In order to maximize stability for long-term recording, mi- cromanipulators (Narashige, MO103) for " puffer" pipettes were mounted on the microscope stage. The microscope was mounted on an air table. The patch-clamp headstage was mounted on a translator stage (Newport Instruments) that was mounted directly on the air table. The cells were bathed in 1 of the external solutions listed in Table 1. For whole-cell recordings, the pipettes were filled with 1 of the internal solutions listed in Table 1. The solutions used in each experiment are described in Results.

Test substances were applied by pressure ejection from micropipettes with tip diameters of $2-5 \mu \mathrm{m}$. The duration of the pressure pulse, unless otherwise specified, was $500 \mathrm{msec}$ and was controlled by the opening and closing of a solenoid valve in the pressure line. When the solenoid closed, it vented the pipette to the outside so that no residual pressure was applied to force test solutions from the pipette. All test solutions that were pressure applied were dissolved in the same external solution that bathed the cells. Puffer pipettes were placed about $20 \mu \mathrm{m}$ from the test cell, with the pipette pointed toward the cell body. By observing puffs from dye-filled pipettes, we determined that a $500-\mathrm{msec}$ puffer application produced a cloud of dye approximately $0.5 \mathrm{~mm}$ in diameter. This puffer application should supply the test substance to most or all of the dendritic tree of the SPN, as well as to the cell body. Recordings were made at room temperature except where otherwise noted. Data were collected only from cells having resting membrane potentials more negative than $-30 \mathrm{mV}$ and input resistances of $>100 \mathrm{M} \Omega$.

The peak current responses of each cell to standard applications of neurotransmitter were used as an indicator of the cell's responsiveness to each neurotransmitter. Standard applications of neurotransmitters consisted of 500-msec puffs of transmitter at a concentration near that which produced a half-maximal response of the SPNs to that transmitter. The half-maximal response concentrations were determined in studies reported in the initial sections of this paper. All peak current measurements were made to the nearest $5 \mathrm{pA}$. Currents with amplitudes of less than $5 \mathrm{pA}$ were not distinguishable above noise and were therefore reported as $0 \mathrm{pA}$. Any cell with a 5-pA or greater current response to the standard application of neurotransmitter was considered to be responsive to that neurotransmitter. When data were pooled to obtain mean peak current values, data from all cells were counted, including $0 \mathrm{pA}$ for unresponsive cells. The capacitance of each cell was calculated from the average capacitative current response to 25 successive test pulses of $10 \mathrm{mV}$.

A possible concern with the recordings from cells in culture from the second day on was that they developed an extensive dendritic tree. It is possible that the quality of space clamp in such cells is not as good as in smaller cells. If this were the case, the actual responses from older cells would be even larger than reported. This would further accentuate the trends we report here.

Iontophoretic mapping. Whole-cell recording as described above was also used to measure the current responses of SPNs to iontophoretic applications of GABA, glycine, and glutamate. Standard fine-tipped microelectrodes were used for iontophoretic application of the transmitters. Iontophoretic current was delivered using a Getting Model 5A microelectrode amplifier. Neurotransmitter substances were applied at a concentration of 1-2 $\mathrm{M}$. For the iontophoretic mapping of GABA currents that are reported here, a 50-nA current ejection for $5 \mathrm{msec}$ was used.

Statistical tests. The statistical test used for comparing mean values of measurements under varying culture conditions was the KruskalWallis 1-way analysis of variance (ANOVA) by ranks (Kruskal and Wallis, 1952). This nonparametric statistic was chosen because the distributions were often not normal, and therefore, a $t$ test was formally not appropriate. However, when a Student's $t$ test was applied to the data, very similar results to those reported were obtained. Results were considered significant if $p<0.05$.

\section{Results}

\section{Composition of cell cultures}

Twenty-four hr after plating, fluorescently labeled SPNs appeared as round balls with only occasional cells having short processes. Non-neuronal cells appeared as flat, irregularly shaped cells. There were many other unlabeled round cells with occasional processes; these were presumably interneurons. Because non-neuronal cells continued to proliferate in vitro and some neurons died, by day 5 in vitro, non-neuronal cells far outnum- 
bered neurons and formed a thick mat underneath the neurons (see Honig and Hume, 1986, their Fig. 4).

\section{Responses of SPNs to neurotransmitters}

We tested the responses of SPNs on days 4-6 in culture to short puffer applications of GABA, glycine, glutamate, serotonin, and norepinephrine. After $4 \mathrm{~d}$ in culture, most SPNs were responsive to GABA, glycine, and glutamate. We did not, however, detect responses to either serotonin or norepinephrine (at concentrations of $1 \mu \mathrm{M}$ to $1 \mathrm{mM}$ ) in any of the SPNs studied using wholecell recording. Because these transmitters often activate receptors that use second-messenger systems, we considered the possibility that responses to serotonin and norepinephrine might have been disrupted by the internal dialysis that accompanies whole-cell recording, or by recording at room temperature. However, when we made intracellular recordings with fine-tipped micropipettes from SPNs maintained at $37^{\circ} \mathrm{C}$ by a temperaturecontrolled bath, we still saw no responses to these substances. In the article that follows (Clendening and Hume, 1990), therefore, we only studied responses of SPNs to GABA, glycine, and glutamate. All experiments were carried out at room temperaturc.

For our standard recording conditions, we used an internal solution with a relatively high concentration of chloride (normal internal solution). In this solution, all 3 amino acid neurotransmitters, GABA, glycine, and glutamate, produced inward currents when SPNs were held at their typical resting membrane potential of $-45 \mathrm{mV}$ (Fig. 1).

\section{Responses to $G A B A$}

Under whole-cell patch clamp, peak GABA currents varied linearly with holding potentials between -80 and $+30 \mathrm{mV}$, and in our standard recording solutions, GABA currents reversed at $-7 \pm 4.2 \mathrm{mV}(n=20)$. Figure $2 A$ shows a current-voltage relationship for a typical SPN, with a GABA reversal potential of $-7.5 \mathrm{mV}$. The reversal potential for GABA currents changed systematically with the chloride concentration of the internal solution in a manner consistent with a channel in which chloride is the major current-carrying ion. When internal chloride concentration was increased from 79 to $142 \mathrm{~mm}$, the GABA reversal potential shifted $17 \mathrm{mV}$ in a depolarizing direction. When internal chloride was decreased to $16 \mathrm{~mm}$, the GABA reversal potential shifted $43 \mathrm{mV}$ in the hyperpolarizing direction (Fig. $2 A$ ). The magnitude of these shifts in membrane potential was equivalent to those predicted by the Nernst equation; however, the actual values for the reversal potentials were shifted about $10 \mathrm{mV}$ in a depolarizing direction from predicted values. This suggests that our measurements include an uncompensated junction potential.

The concentration-response relationship for the action of GABA on SPNs is illustrated in Figure 2B. The concentration of GABA that produced a half-maximal response was close to $100 \mu \mathrm{M}$. SPN responses to $100 \mu \mathrm{M}$ GABA were completely and reversibly blocked by $10 \mu \mathrm{M}$ bicuculline and $100 \mu \mathrm{M}$ picrotoxin (Fig. 2C). Responses to $100 \mu \mathrm{M}$ GABA were also blocked by the glycine-receptor antagonist strychnine, but only at very high ( $2 \mathrm{mM}$ ) concentrations (Fig. $2 C$ ). Strychnine at a concentration that completely blocked glycine currents $(500 \mu \mathrm{M})$ partially inhibited GABA-evoked responses.

On the basis of their physiology and pharmacology, therefore, these responses to GABA are typical of those described in other systems for the GABA A receptor (Barker and Ransom, 1978;
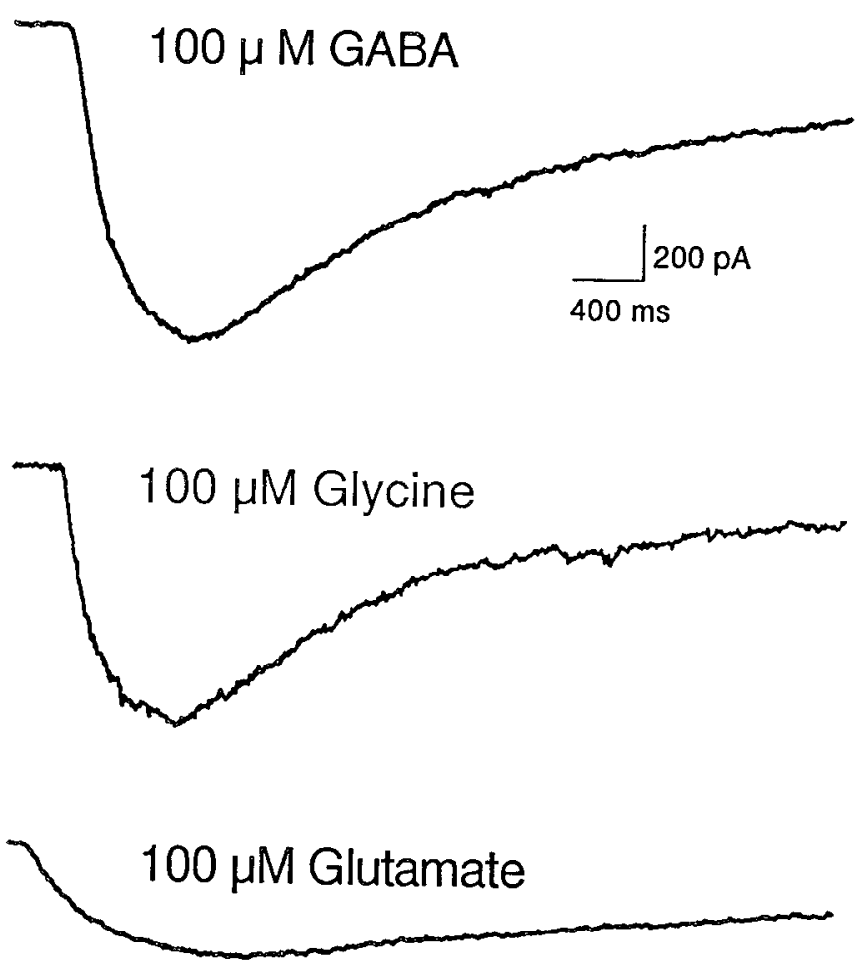

Figure 1. Preganglionic neurons respond to multiple amino acid transmitters. Whole-cell current responses of a single SPN to 500-msec puffer applications of $100 \mu \mathrm{M}$ GABA, $100 \mu \mathrm{M}$ glycine, and $100 \mu \mathrm{M}$ glutamate are shown. This neuron was from a 6-d culture and was bathed in normal external solution. The recording pipette contained normal internal solution; the high internal chloride concentration $(79 \mathrm{~mm})$ of this solution resulted in inward current responses to all 3 neurotransmitters.

Macdonald et al., 1982; Nowak et al., 1982; Segal and Barker, 1984).

\section{Responses to glycine}

Peak glycine currents in SPNs also varied linearly under wholecell patch clamp with holding potentials between -80 and +30 $\mathrm{mV}$. Using our standard recording solutions, the reversal potential for glycine currents was $-4.4 \pm 3.6 \mathrm{mV}(n=20)$. Figure $3 \mathrm{~A}$ shows the current-voltage relationship for a typical SPN, with a glycine reversal potential of $0 \mathrm{mV}$. The reversal potential of glycine currents also varied systematically with changes in the concentration of chloride in our internal recording solution (Fig. 3A). When the internal chloride concentration was increased from 79 to $142 \mathrm{~mm}$, the glycine reversal potential shifted $15 \mathrm{mV}$ in a depolarizing direction. When internal chloride was decreased to $16 \mathrm{~mm}$, the glycine reversal potential shifted 45 $\mathrm{mV}$ in the hyperpolarizing direction. Again, the magnitude of these shifts was equivalent to those predicted by the Nernst equation, but the actual values were not, suggesting the presence of an uncompensated junction potential.

A concentration-response relationship for the action of glycine on SPNs is illustrated in Figure $3 B$. The half-maximal response of SPNs to glycine was close to $250 \mu \mathrm{M}$. A high concentration $(500 \mu \mathrm{M})$ of strychnine was needed to completely block the responses of SPNs to $100 \mu \mathrm{M}$ glycine. This is a significantly less potent blocking effect than has been reported for other cells, where strychnine is effective at the nanomolar level (Aprison and Daly, 1978; Barker and Ransom, 1978; Pfeiffer 

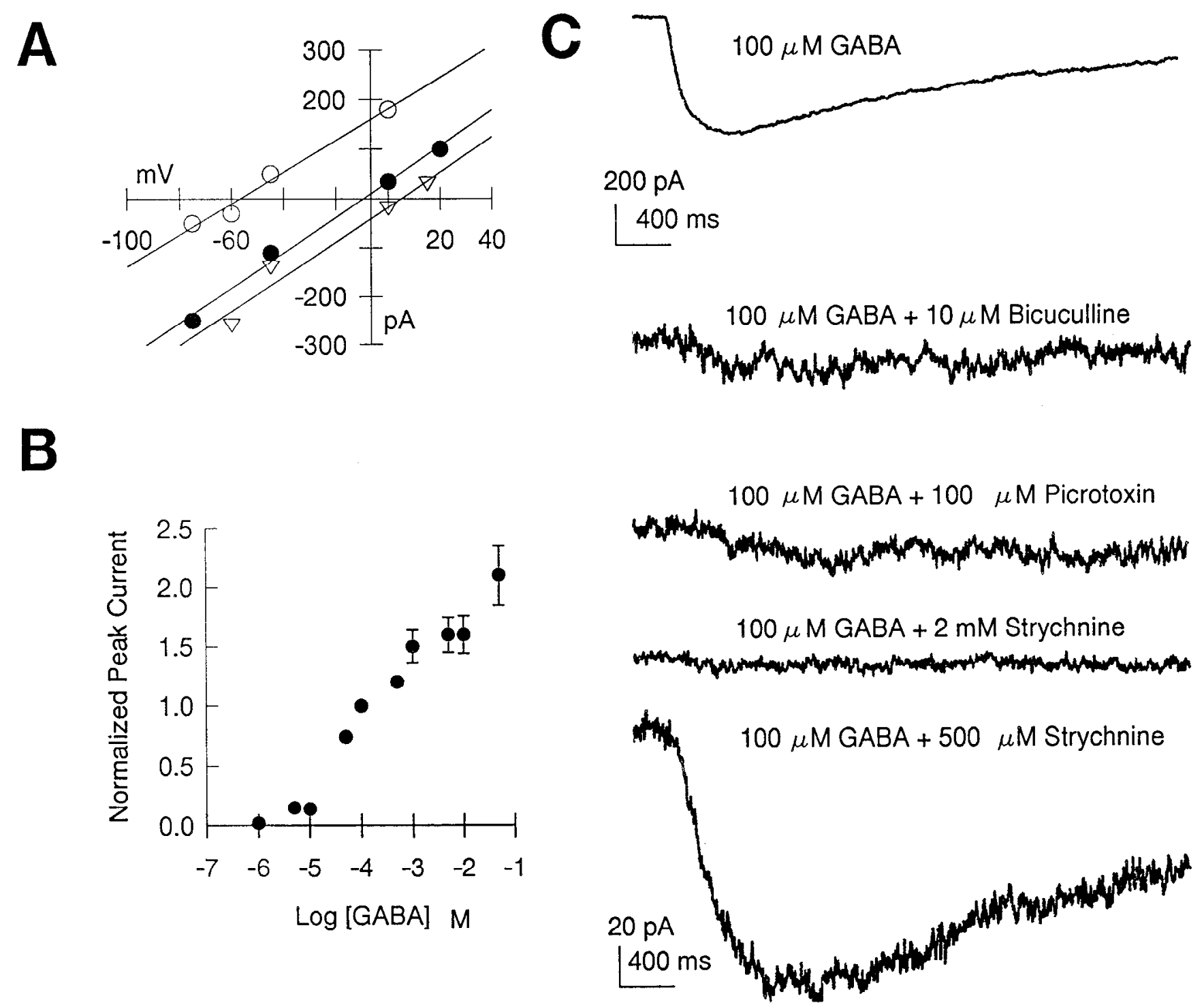

Figure 2. Characterization of GABA responses. $A$, Current-voltage relationship at 3 different internal chloride concentrations. Data were taken from 3 different cells in the same culture dish. Each point represents the peak current measured in response to a 500 -msec puffer application of $100 \mu \mathrm{M}$ GABA when membrane potential was held at the indicated level. Normal external solution was used in all cases. The internal solution contained $16 \mathrm{~mm}$ (open circles), $79 \mathrm{~mm}$ (solid circles), or $142 \mathrm{~mm}$ (triangles) chloride. For each of the chloride concentrations, 15 cells were studied, all of which gave results similar to those shown here. $B$, GABA concentration-response curve. Each SPN was tested with $100 \mu \mathrm{M}$ GABA and 2 additional concentrations of GABA. The peak current response to each concentration was measured and then normalized by dividing by the peak current response of that cell to $100 \mu \mathrm{M}$ GABA. Each point represents the mean \pm SEM of data collected from 10 cells. For several points, the SEM was smaller than the symbols and is therefore not shown. In all cases, the holding potential was $-45 \mathrm{mV}$, and normal internal and external solutions were used. $C$, SPN responses to specific antagonists of GABA receptors and glycine receptors. The top trace is typical of the response of SPNs to a 500-msec puffer application of $100 \mu \mathrm{M}$ GABA. Traces 2 and 3 are responses of the same cell to the simultaneous application of $100 \mu \mathrm{M}$ GABA with $10 \mu \mathrm{M}$ bicuculline or $100 \mu \mathrm{M}$ GABA with $100 \mu \mathrm{M}$ picrotoxin, respectively. Note the change in gain for traces $2-5$. Both of these GABA ${ }_{\mathrm{A}}-$ receptor antagonists eliminated the GABA response. Traces 4 and 5 were recorded from a cell with similar resting membrane potential, input resistance, membrane capacitance, and response to GABA as the cell used for the first 3 traces. They show that $500 \mu \mathrm{M}$ strychnine, which was sufficient to totally block the response of SPNs to glycine (see Fig. 3), also partially blocked the response to $100 \mu \mathrm{M}$ GABA, and that 2 mM strychnine completely blocked the response to $100 \mu \mathrm{M}$ GABA.

et al., 1982). Glycine responses were also completely blocked by $5 \mathrm{~mm}$ picrotoxin and partially blocked by lower concentrations of this drug.

The relative insensitivity of glycine receptors on SPNs to strychnine is interesting in light of the recent finding of Becker et al. (1988) that there are 2 isoforms of the glycine receptor in the rat spinal cord. One of the isoforms is sensitive to strychnine and is found primarily in the adult spinal cord. The other form is relatively insensitive to strychnine and is found exclusively in the embryonic and neonatal spinal cord. It is likely that the glycine responses we see are the result of activation of an embryonic, strychnine-insensitive form of the glycine receptor.

Based on the linear current-voltage relationship and the chloride dependence of the glycine reversal potential, the glycine responses of SPNs are typical of the glycine receptor described by others (Barker and Ransom, 1978; Macdonald et al., 1982). 
A

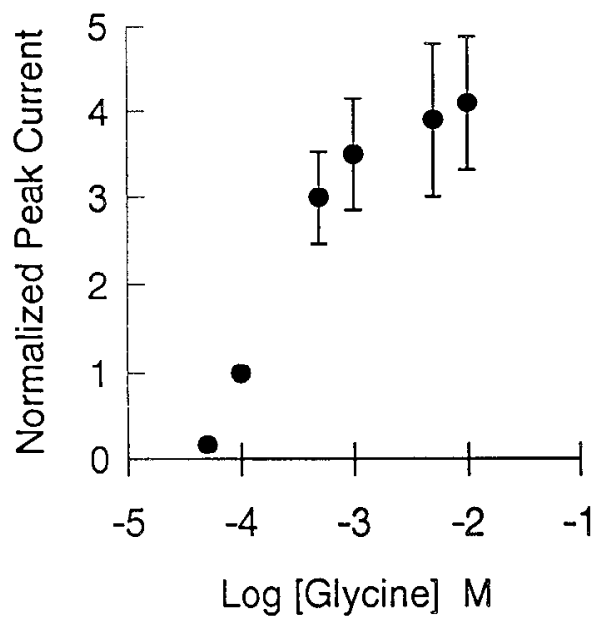

c

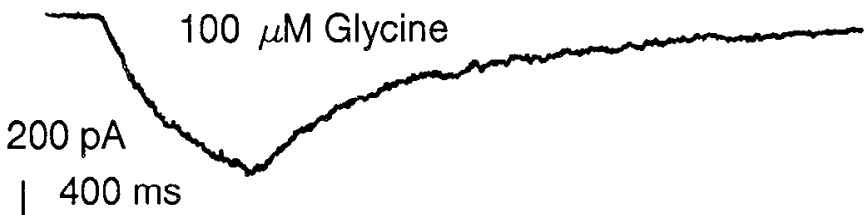

$100 \mu \mathrm{M}$ Glycine $+100 \mu \mathrm{M}$ Strychnine

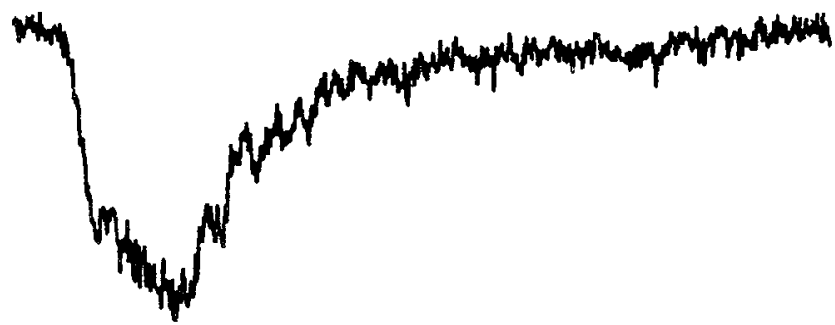

$100 \mu \mathrm{M}$ Glycine $+500 \mu \mathrm{M}$ Strychnine
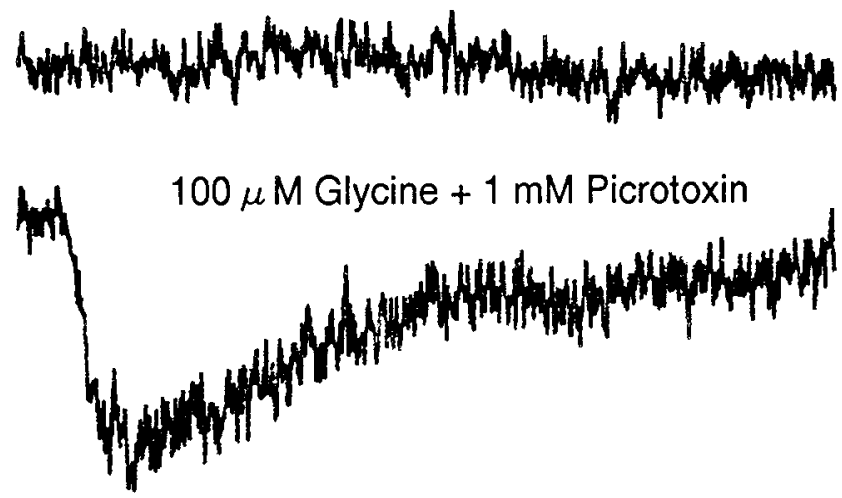

$100 \mu \mathrm{M}$ Glycine $+5 \mathrm{mM}$ Picrotoxin

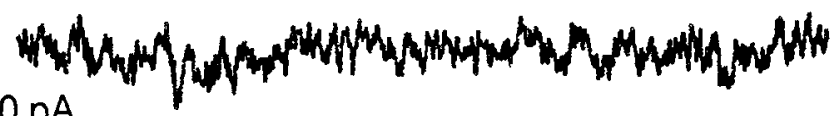

$20 \mathrm{pA}$

$400 \mathrm{~ms}$

Figure 3. Characterization of glycine responses. $A$, Current-voltage relationship at different internal chloride concentrations. Data wcrc taken from 3 different cells in the same culture dish. Each point represents the peak current measured in response to a 500-msec puffer application of $100 \mu \mathrm{M}$ glycine when the cell was held at the indicated membrane potential. Normal external solution bathed the cells. The internal solution contained $16 \mathrm{~mm}$ (open circles), $79 \mathrm{~mm}$ (solid circles), or $142 \mathrm{~mm}$ (triangles) chloride. For each chloride concentration, 15 cells were studied, all of which gave similar results. $B$, Glycine concentration-response curve. Each SPN was tested with $100 \mu \mathrm{M}$ glycine and 2 additional concentrations of glycine. The peak current response to each concentration was measured and then normalized by dividing by the peak current response of that cell to $100 \mu \mathrm{M}$ glycine. Each point represents the mean \pm SEM of data collected from 10 cells. For some points, the SEM was smaller than the symbol, and it is therefore not shown. In all cases, the holding potential was $-45 \mathrm{mV}$, and normal internal and external solutions were used. $C$, SPN responses to specific glycine-receptor and $\mathrm{GABA}_{\Lambda}$-receptor antagonists. The top trace is typical of the responses of SPN to 500-msec puffer applications of $100 \mu \mathrm{M}$ glycine. Traces 2 and 3 are the responses of the same cell to the simultaneous applications of $100 \mu \mathrm{M}$ glycine with $100 \mu \mathrm{M}$ strychnine or $100 \mu \mathrm{M}$ glycine with $500 \mu \mathrm{M}$ strychnine, respectively. Note the change in gain for traces $2-5$. Traces 4 and 5 were recorded from a cell with similar membrane properties and responses to glycine as the cell from which traces $1-3$ were recorded. They show the responses of this cell to $100 \mu \mathrm{M}$ glycine and $1 \mathrm{mM} \cdot$ picrotoxin or $100 \mu \mathrm{M}$ glycine and $5 \mathrm{~mm}$ picrotoxin, respectively.

\section{Responses to glutamate}

The response of SPNs to puffer applications of glutamate (100 $\mu \mathrm{M})$ was similar to previously reported glutamate responses of mouse CNS cells (Mayer et al., 1984; Nowak et al., 1984) and chick spinal cord neurons (O'Brien and Fischbach, 1986b; Vlachova et al., 1987). Under our normal recording conditions (using a $\mathrm{Mg}^{2+}$-containing bath solution), maximum inward currents in response to glutamate application were seen when SPNs were held at $-20 \mathrm{mV}$ (Fig. $4 A$ ). The amplitude of inward cur- rents decreased at holding potentials positive to this and reversed between +5 and $+10 \mathrm{mV}$. Inward current amplitude also decreased at holding potentials between -20 and $-80 \mathrm{mV}$, thus producing a current-voltage relationship with a region of negative-slope conductance. This nonlinearity in the currentvoltage relationship disappeared when the cells were bathed in a $\mathrm{Mg}^{2+}$-free external solution (Fig. 4A). The apparent voltage dependence of the glutamate response thus can be assigned to the voltage dependence of $\mathrm{Mg}^{2+}$ block as described by Nowak et al. (1984) and Mayer and Westbrook (1985). Changing the 

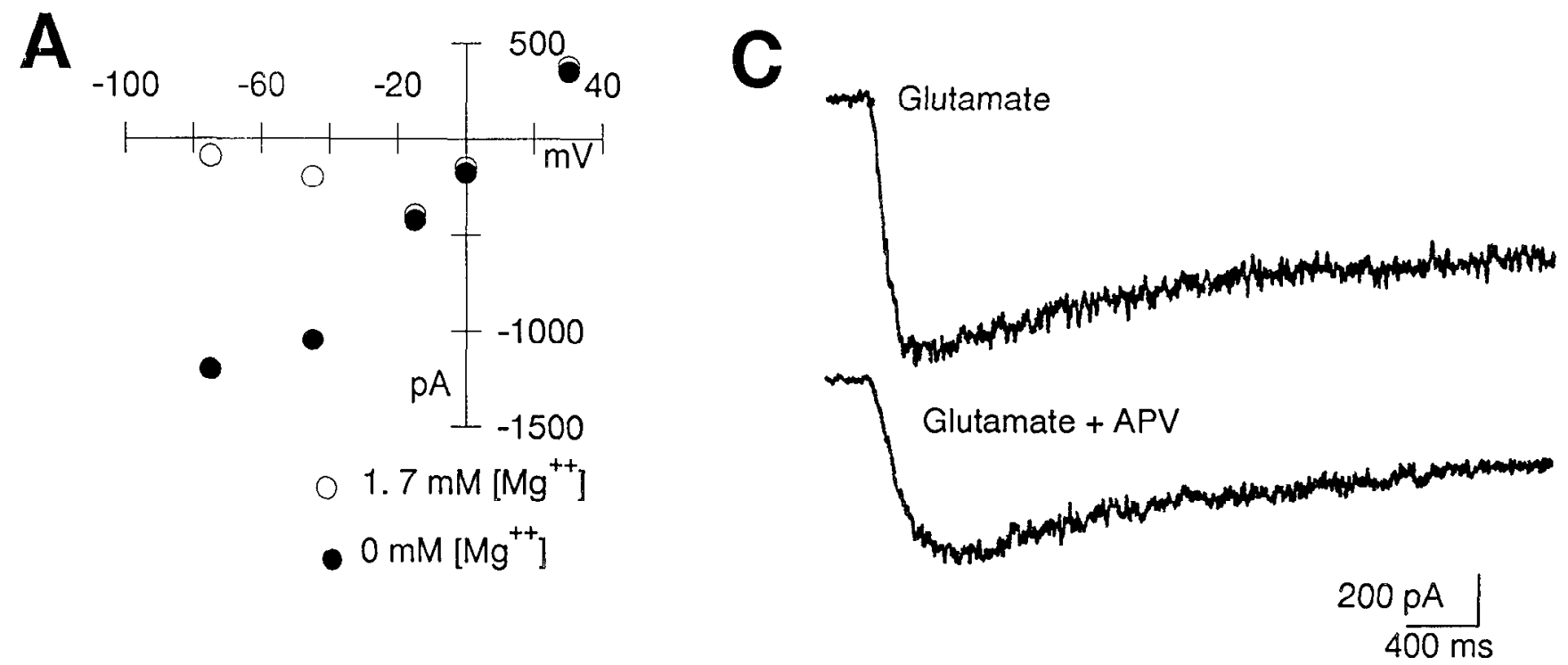

B

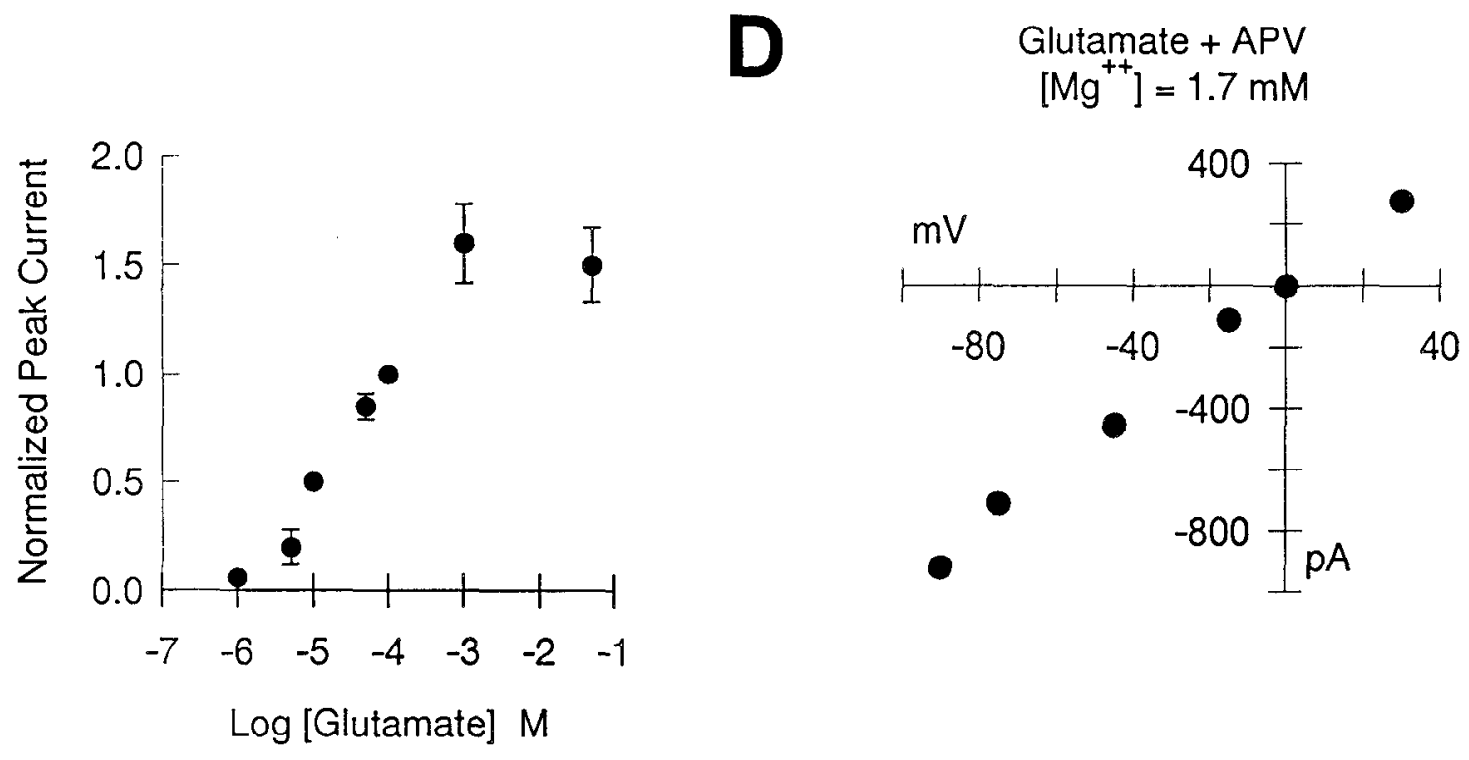

Figure 4. Characterization of glutamate responses. A, Glutamate current-voltage relationship in normal external solution (containing $1.7 \mathrm{~mm}$ $\mathrm{Mg}^{2+}$; open circles) and in $\mathrm{Mg}^{2+}$-free external solutions (solid circles). Both sets of data were collected from the same cell. Data were first collected with normal external solution bathing the cell, then the bath solution was exchanged by a gravity-fed perfusion system. Each point represents the peak current measured in response to a $500-\mathrm{msec}$ puffer application of $100 \mu \mathrm{M}$ glutamate. Normal internal solution was used. $B$, Glutamate concentration-response curve. Each SPN was tested with $100 \mu \mathrm{M}$ glutamate and 2 additional concentrations of glutamate. The peak current response to each concentration was measured and then normalized by dividing by the peak current response of that cell to $100 \mu \mathrm{M}$ glutamate. Each point represents the mean \pm SEM of the data collected from 10 cells. For some points, the SEM was smaller than the symbol and is therefore not shown. In all cases, the holding potential was $-45 \mathrm{mV}$, and normal internal and $\mathrm{Mg}^{2+}$-free external solutions were used. $C$, Partial block of glutamate response by APV. The top trace is typical of the responses of SPNs to a 500-msec puffer application of $100 \mu \mathrm{M}$ glutamate. The bottom trace is the response of the same cell when $100 \mu \mathrm{M}$ APV was applied simultaneously with $100 \mu \mathrm{M}$ glutamate. Holding potential was $-45 \mathrm{mV}$ in both cases; normal internal and $\mathrm{Mg}^{2+}$-free external solutions were used in both cases. $D$. Current-voltage relationship of an SPN in response to glutamate and APV in $\mathrm{Mg}^{2+}$-containing external solution. Each point represents the peak current recorded in response to 500 -msec puffer applications of $100 \mu \mathrm{M}$ glutamate and $100 \mu \mathrm{M}$ APV. The cells were bathed in normal $\left(\mathrm{Mg}^{2+}\right.$-containing) external solution, and normal internal solution was used. In the presence of APV, the current-voltage relationship of the glutamate-evoked currents was linear even in the presence of magnesium.

internal chloride concentration had no effect on the reversal potential for glutamate. We did not undertake other ion-substitution experiments; however, the reversal potential for glutamate currents suggests a nonselective cation channel, A concentration-response relationship for the action of glutamate on preganglionic neurons is illustrated in Figure $4 B$. The concentration of glutamate that produced a half-maximal response was near $50 \mu \mathrm{M}$. The response of SPNs to $50 \mu \mathrm{M}$ glutamate was completely blocked by kynurenic acid but only at high concentrations (1 $\mathrm{mm}$ or greater).

Glutamate is able to activate several different pharmacologically defined receptor subtypes. The substances NMDA, kainate, and quisqualate are generally considered to be selective agonists for 3 different receptors (Watkins and Evans, 1981; Foster and Fagg, 1984; but see O'Brien and Fischbach, 1986b). The NMDA receptor is selectively blocked by $\mathrm{D}-2$-amino-5- 
phosphonovalerate (APV; Evans et al., 1982), and the channels activated by the NMDA receptor have been shown to exhibit voltage-dependent block by $\mathrm{Mg}^{2+}$ (Mayer and Westbrook, 1985). Because the responses of SPNs to glutamate showed a $\mathrm{Mg}^{2+}$ dependent block, we suspected that at least some of the glutamate response was due to activation of NMDA receptors. In both normal and $\mathrm{Mg}^{2+}$-free solutions, the responses of SPNs to $100 \mu \mathrm{M}$ glutamate were partially blocked by $100 \mu \mathrm{M}$ APV (Fig. $4 C$ ). In addition, when $100 \mu \mathrm{M} \mathrm{APV}$ was added to our normal external solution (with $1.7 \mathrm{mM} \mathrm{Mg}^{2+}$ ), the remaining glutamateactivated current had a current-voltage relationship that was linear at both positive and negative potentials (Fig. $4 D$ ). These results strongly suggest that SPNs express both NMDA and nonNMDA receptors. We therefore tested the responses of SPN to the 3 selective agonists, NMDA, kainate, and quisqualate. Under our normal whole-cell recording conditions, SPNs held at $-45 \mathrm{mV}$ responded to the application of NMDA, kainate, and quisqualate with inward currents. Analysis of the concentrationresponse relationships of the action of these 3 substances indicated that the concentrations needed for half-maximal activation of inward currents were near $100 \mu \mathrm{M}, 100 \mu \mathrm{M}$, and $1 \mu \mathrm{M}$, respectively (Fig. 5). In most cells, the quisqualate-evoked currents were much smaller than those evoked by either NMDA or kainate.

When recordings were made from cells bathed in $\mathrm{Mg}^{2+}$-containing solution, the current-voltage relationship for $100 \mu \mathrm{M}$ NMDA showed an area of negative-slope conductance between -30 and $-80 \mathrm{mV}$ and had a reversal potential of $+12 \pm 4$ $\mathrm{mV}$, but when the cells were bathed in a $\mathrm{Mg}^{2+}$-free solution, the current-voltage relationship was linear throughout the range of holding potentials from -80 to $+30 \mathrm{mV}$. Figure $6 \mathrm{~A}$ shows the current-voltage relationship of a typical SPN bathed first in normal external solution and then in $\mathrm{Mg}^{2+}$-free external solution. The reversal potential for NMDA in this cell was +15 $\mathrm{mV}$. SPN responses to NMDA were completely and reversibly blocked by concurrent application of $100 \mu \mathrm{M}$ APV. In contrast, SPN responses to $100 \mu \mathrm{M}$ kainate and to $1 \mu \mathrm{M}$ quisqualate showed a linear current-voltage relationship between -80 and $130 \mathrm{mV}$ whether or not magnesium was present (Fig. $6 B, C$ ). The reversal potential for both kainate and quisqualate fell between 0 and $-5 \mathrm{mV}$. SPN responses to kainate and quisqualate were unaffected by concurrent applications of APV at concentrations up to $5 \mathrm{~mm}$.

The responses of SPNs to the application of NMDA were similar to those reported for mouse cortical and diencephalic cells and mouse spinal neurons (Mayer and Westbrook, 1985; Nowak et al., 1984), and the responses of chick SPNs to the application of kainate and quisqualate were similar to the previously reported responses of chick spinal-cord cells and mouse hippocampal cells to these substances (O'Brien and Fischbach, 1986b; Vlachova et al., 1987; Trussell et al., 1988).

\section{Range of responses to $G A B A$, glycine, and glutamate and relation of responses to synapse formation}

For each plating of cells, there was a huge amount of cell-tocell variation in the responsiveness of SPNs to GABA, glycine, and glutamate. For instance, at day 5 in vitro, the peak responses of SPNs to GABA ranged from -10 to $-4600 \mathrm{pA}$, the peak responses of SPNs to glycine ranged from 0 to $-1760 \mathrm{pA}$, and the peak responses of SPNs to glutamate ranged from 0 to -1821 pA. Thus, the variability in the responses of unidentified CNS cells seen by others (Ransom et al., 1977) was not necessarily
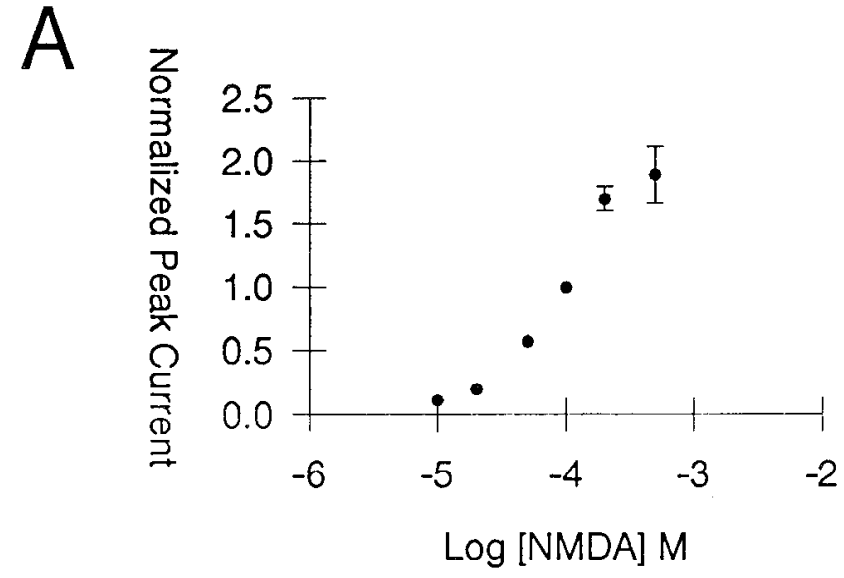

B
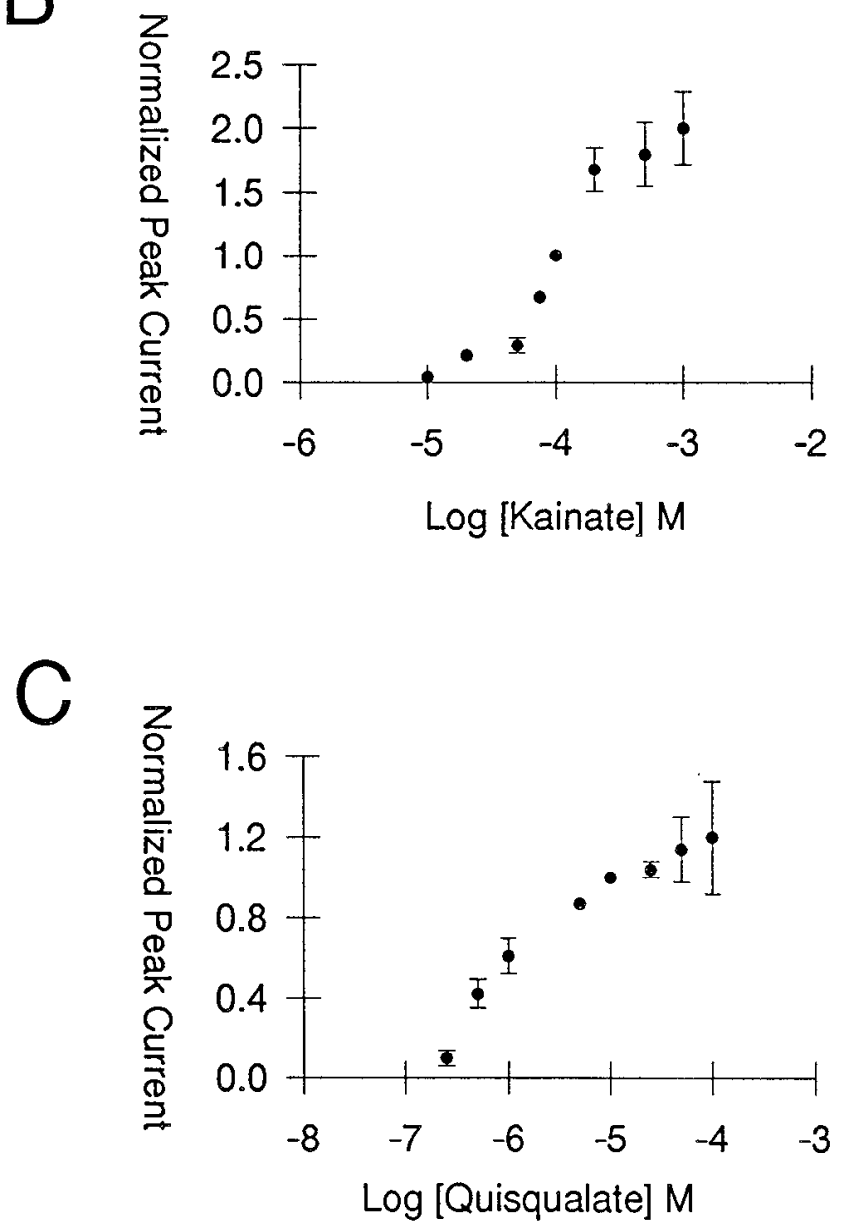

Figure 5. Concentration-response curves for glutamate-receptor subtype-specific agonists. $A$, NMDA. $B$, Kainate. $C$, Quisqualate. SPNs were tested with $500-\mathrm{msec}$ puffer applications of the agonists. Each cell was tested with a standard concentration of an agonist and 2 other concentrations of that same agonist. Peak current responses of a cell to the 3 different concentrations of agonist were measured and normalized by dividing the peak current response at that concentration by the response to the standard concentration. For NMDA and kainate, the standard concentration was $100 \mu \mathrm{M}$, while for quisqualate, the standard concentration was $10 \mu \mathrm{M}$. Each point represents the mean \pm SEM of data collected from at least 5 cells. In some cases, the SEM was smaller than the symbol and is therefore not shown. In all cases, the holding potential was $-45 \mathrm{mV}$, and normal internal and $\mathrm{Mg}^{2+}$-free external solutions were used. 

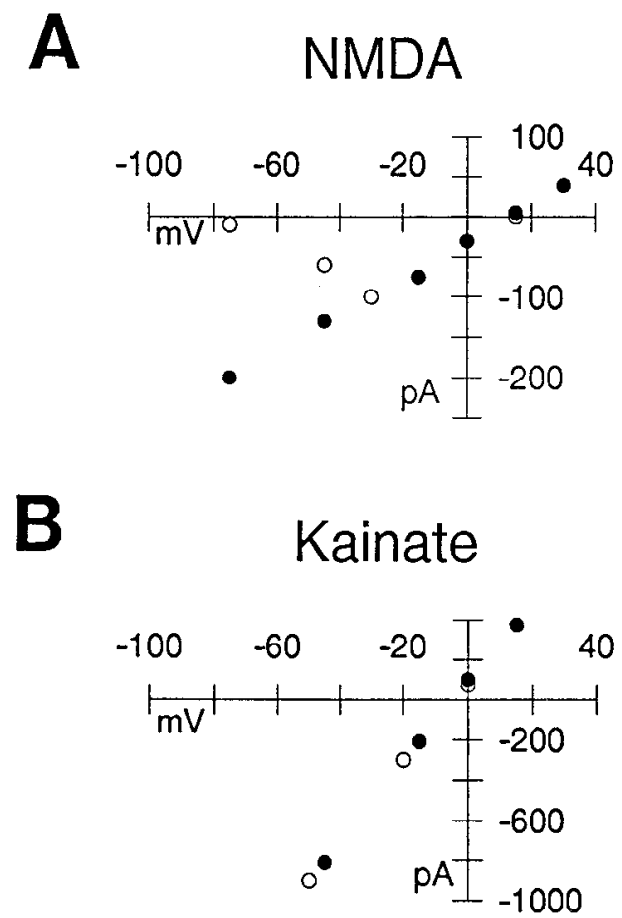

\section{Quisqualate}

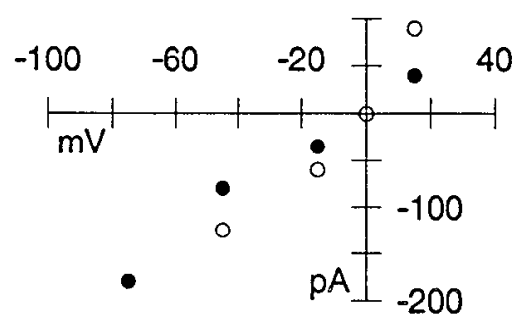

$$
01.7 \mathrm{mM} \mathrm{Mg}^{++} \quad 0 \mathrm{mM} \mathrm{Mg}^{++}
$$

Figure 6. Current-voltage relationships for glutamate-receptor subtype-specific agonists. $A$, NMDA, $100 \mu \mathrm{M}$. $B$, Kainate, $100 \mu \mathrm{M}$. C, Quisqualate, $1 \mu \mathrm{M}$. In all cases, the agonist was applied by 500 -msec puffs, and normal internal solution was used. Either normal (open circles) or $\mathrm{Mg}^{2+}$-free (solid circles) external solution bathed the cells. Data in $A$ were all taken from the same cell. The cell was initially bathed in $\mathrm{Mg}^{2+}$ free solution, and the bath solution was then exchanged to normal external solution using a gravity-fed perfusion system. In $B$ and $C$, data were obtained from 2 different cells.

due to cell heterogeneity, because a similar variability was seen in these cells, which are all of the same type. The size of SPNs at day 7 also varied widely. The input capacitance of cells (an indicator of cell size) tested on day 5 in vitro ranged from 4 to $86 \mathrm{pF}$. However, there was no significant correlation between cell capacitance and responsiveness to any of these neurotransmitters. The calculated coefficent of determination $\left(r^{2}\right)$ for the best linear fit of the data taken from SPNs at day 5 in vitro was $<0.1$ for all 3 transmitters.

We considered the possibility that the variability in responsiveness was due to differences in the number of synapses on
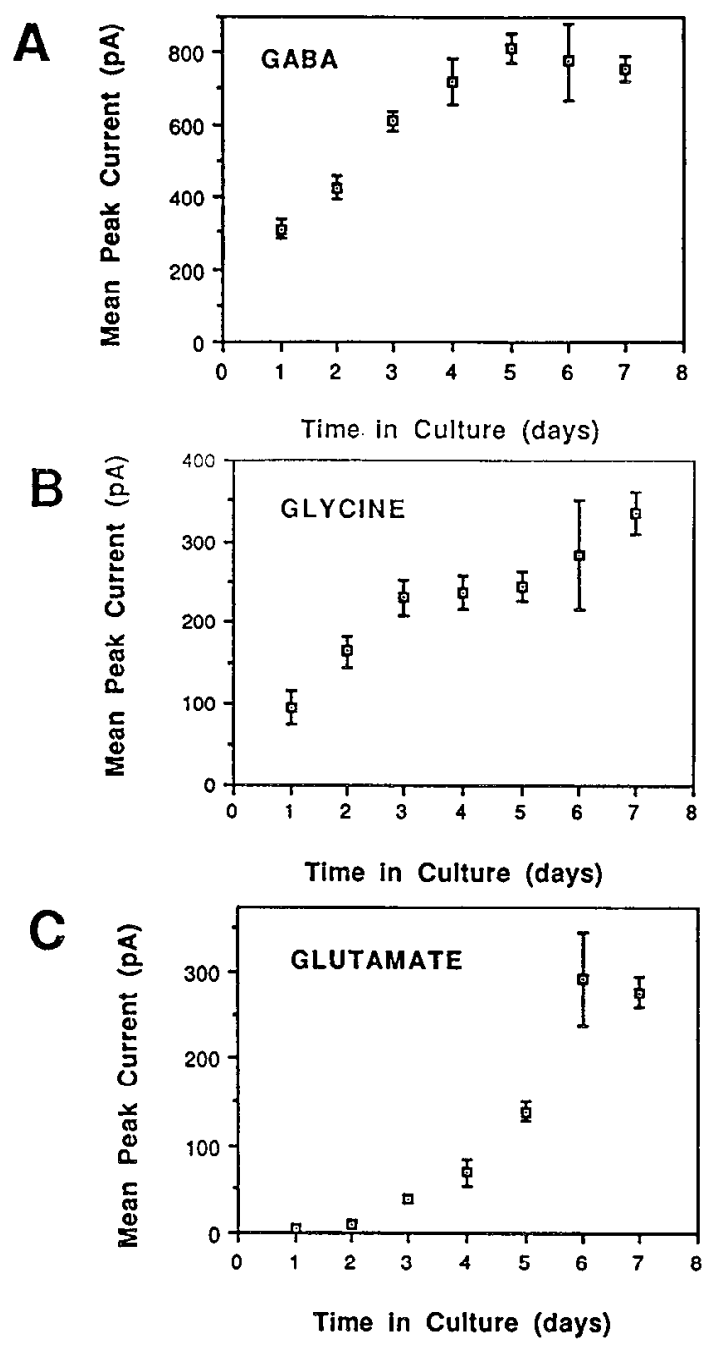

Figure 7. Time course of appearance of responsiveness to GABA, glycine, and glutamate. Peak current responses of SPNs to 500-msec puffer applications of GABA, glycine, and glutamate at concentrations near those that evoked half-maximal responses were measured on days 1-7 in vitro. Concentrations used were $100 \mu \mathrm{MGABA}(A), 250 \mu \mathrm{M}$ glycine $(B), 50 \mu \mathrm{M}$ glutamate $(C)$. Cells were usually held at $-45 \mathrm{mV}$. If the current saturated the head stage of the amplifier $(>1 \mathrm{nA})$, the cell was studied at potentials closer to 0 , and the value at -45 was extrapolated using the experimentally measured current-voltage curves. In all cases, normal internal and $\mathrm{Mg}^{2+}$-free external solutions were used. Each point represents the mean \pm SEM of data collccted from more than 100 cells from 10 or more separate platings. Two additional experiments were also performed using $100 \mu \mathrm{M}$ glycine, as well as 3 additional experiments using $100 \mu \mathrm{M}$ glutamate. Comparable results for the time course of development of responsiveness were found in these experiments.

cells. At day 3 in vitro, a few SPNs exhibited spontaneous postsynaptic currents. On days 5-7 in vitro, many SPNs showed frequent postsynaptic currents that, with our normal internal recording solution (relatively high $\mathrm{Cl}^{-}$concentration), all appeared as inward currents. The number of SPNs showing postsynaptic currents varied widely from plating to plating. Although we did not do a quantitative analysis, we observed many cells that had frequent postsynaptic currents but small responses to each of the 3 neurotransmitters. Likewise, we observed many SPNs with no apparent synaptic currents that had large responses to all 3 neurotransmitters. Therefore, it seems unlikely 
that responsiveness to neurotransmitters is tightly coupled to spontaneous synaptic potentials, though it might still be coupled to the presence of synaptic contacts.

\section{Regulation of the responses of SPNs to neurotransmitters}

\section{Appearance of transmitter responsiveness}

If neurotransmitter receptors are regulated in a coordinate manner on SPNs, then responses to the application of the 3 neurotransmitters should appear along the same time course. To test this prediction, we made a systematic study of the development of the responses of SPNs to the application of GABA, glycine, glutamate, NMDA, kainate, and quisqualate. SPNs were tested for responsiveness to these substances on each day between day 1 and day 7 in culture. Each cell was tested with 3 different compounds. GABA, glycine, and glutamate responses were measured on one set of cells, and NMDA, kainate, and quisqualate responses were measured on a second set of cells. For these experiments, we used a transmitter concentration that was near the half-maximal level for each substance, in order to avoid the desensitization that occurred when saturating levels of transmitter were used. When cells were first tested at $24 \mathrm{hr}$ after plating, most SPNs (97\%) were already sensitive to GABA, and by day $3,100 \%$ of SPNs tested were sensitive to GABA. The mean GABA-activated current increased 2.5-fold over the first $5 \mathrm{~d}$ in culture, then leveled off (Fig. $7 A$ ). A much smaller fraction of the cells gave responses to glutamate or glycine at $24 \mathrm{hr}$ after plating (39\% and $66 \%$, respectively). SPN responses to glycine increased 3 -fold over the first week in culture (Fig. $7 B$ ). For the first $2 \mathrm{~d}$, glutamate evoked small currents in the cells that were sensitive (Fig. 7 C). Mean peak glutamate current increased nearly 7 -fold between days 1 and 3 in vitro, then increased another 7-fold between days 3 and 7 .

The appearance of responsiveness to the 3 glutamate-receptor agonists also occurred with different time courses (Fig. 8). No cells gave detectable responses to quisqualate until $3 \mathrm{~d}$ in vitro, and only 1 of 67 cells responded to NMDA during the first 2 d. In contrast, $50 \%$ of the cells already responded to kainate at day 1 . Therefore, the glutamate responsiveness that was evident at day 1 was probably due exclusively to activation of kainate receptors. By 1 week in vitro, $92 \%$ of the cells tested responded to NMDA, and $96 \%$ responded to kainate, while only $71 \%$ responded to quisqualate. At day 7 in vitro, both NMDA and kainate typically produced currents between 200 and 300 pA, while the quisqualate-activated currents were usually still less than $100 \mathrm{pA}$.

A result that at first seemed unexpected was that the average responses of SPNs to kainate (Fig. 8) were much larger than the average responses of SPNs to glutamate (Fig. 7), over the time period of 1-5 $\mathrm{d}$ in vitro. One might have naively expected that glutamate, which activates all 3 subtypes of receptors, would evoke larger responses than those evoked by any of the individual subtype-specific agonists. The responses to glutamate and kainate were measured in separate platings of cells, but the differences seemed too largc and consistent to be accounted for by variation between platings. A much more likely explanation for these observations is that, for kainate receptors, the efficacy of kainate is much higher than the efficacy of glutamate. Considerable evidence indicates that this is the case in other systems (for review, see Monaghan et al., 1989). In a particularly striking example, Hollman et al. (1989) have isolated a cDNA clone that, on expression in Xenopus oocytes, produces functional ion channels with the electrophysiological and pharmacological
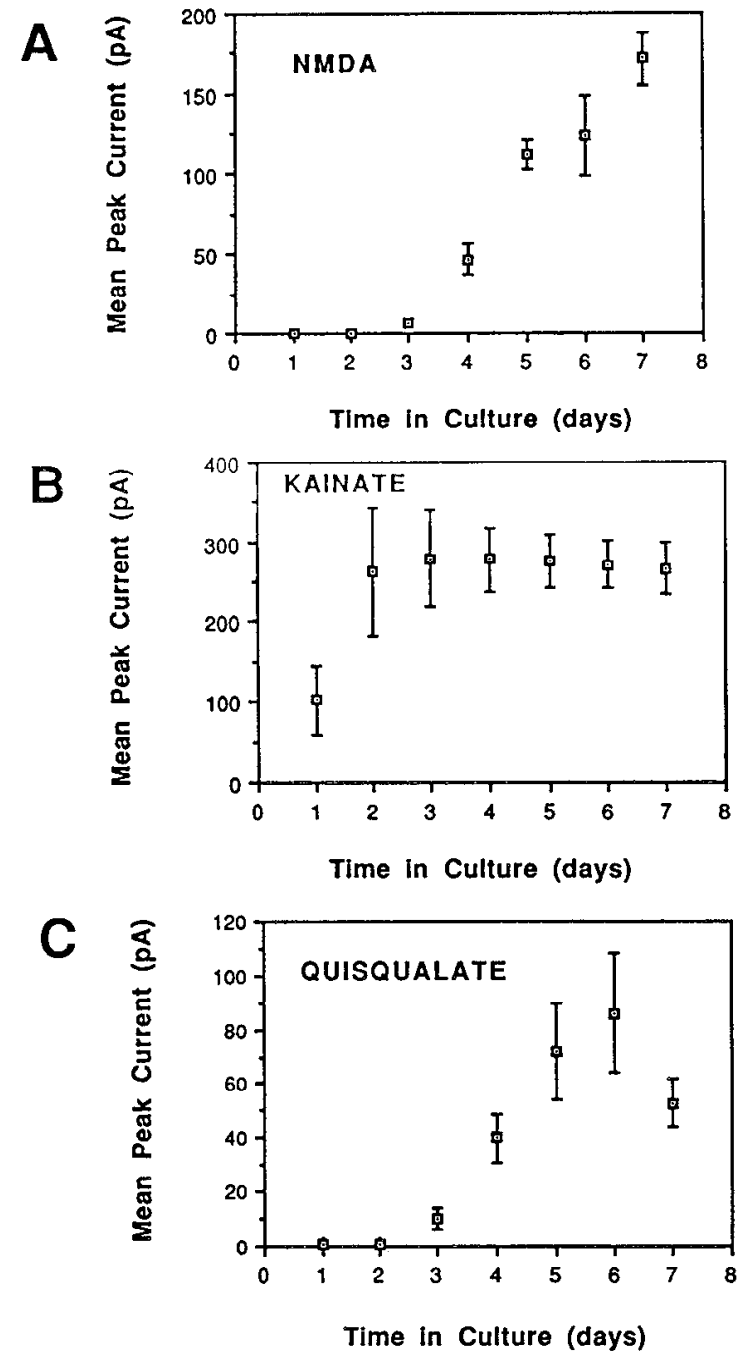

Figure 8. Time course of appearance of responsiveness to NMDA, kainate, and quisqualate. Peak current responses of SPNs to 500 -msec puffer applications of NMDA, kainate, and quisqualate at concentrations near those that evoked half-maximal responses were measured on days 1-7 in vitro. Concentrations uscd were $100 \mu \mathrm{M}$ NMDA $(A), 100$ $\mu \mathrm{M}$ kainate $(B), 1 \mu \mathrm{M}$ quisqualate $(C)$. In most cases, holding potential was -45 . If the current saturated the head stage of the amplifier $(>1$ $\mathrm{nA}$ ), the cell was studied at potentials closer to 0 , and the value at -45 was extrapolated using the experimentally measured current-voltage curves. Normal internal and $\mathbf{M g}^{2+}$-free external solutions were used in all cases. Each point represents the mean \pm SEM of data collected from more than 100 cells from 10 or more platings.

properties of kainate receptors. In oocytes injected with mRNA from this clone, $1 \mathrm{~mm}$ glutamate (likely a saturating concentration) elicited responses that were only $50 \%$ as large as those elicited by $30 \mu \mathrm{M}$ kainate. In SPNs, our studies of responsiveness to quisqualate and NMDA indicated that these types of glutamate receptors were relatively uncommon over the first days of development in vitro, so it is not really surprising that kainate produced larger responses than glutamate.

Although the time-course data are consistent with the idea that different receptors begin to be expressed at different times during development, there are other possible explanations. One possibility is that SPNs in intact day-7 embryos already express all receptors, but that some receptors are particularly sensitive to the protease that we used to dissociate cells. These 
receptors would therefore be absent from SPNs in culture until they could be replaced by newly synthesized receptors. To address this possibility, we examined the effects of exposure to collagenase on the transmitter responsiveness of SPNs in culture. We measured the GABA, glycine, and glutamate responses of a set of 5- and 6-d cultures in which virtually every cell had responses of $>50 \mathrm{pA}$ to the application of each of these neurotransmitters. We then treated these cultures with $0.02 \%$ collagenase dissolved in Puck's solution for $1 \mathrm{hr}$ at $37^{\circ} \mathrm{C}$ (twice as long as during the dissociation process). The dishes were then washed thoroughly, and each culture was retested for responsiveness to each neurotransmitter. The mean peak current responses $(\mathrm{pA}) \pm$ SEM of SPNs $(n=30)$ to GABA, glycine, and glutamate were $524.4 \pm 6.7,105.6 \pm 16.6$, and $35.6 \pm 5.8$, respectively, before collagenase treatment and $512.6 \pm 5.5,131.3$ \pm 16.6 , and $37.0 \pm 5.7$, respectively, after collagenase treatment. There was no significant change in the responsiveness to GABA, glycine, or glutamate after collagenase treatment $(p>$ 0.2 ).

A second possible explanation for the low initial glutamate and glycine responsiveness is suggested by the composition of our standard medium. F12 medium contains $96 \mu \mathrm{M}$ glutamate and $77 \mu \mathrm{M}$ glycine. Although glycine and kainate receptors are not generally observed to desensitize significantly, receptors to NMDA and quisqualate can show considerable desensitization (Aprison and Daly, 1978; Kiskin et al., 1986; Trussell et al., 1988). Furthermore, long-term changes in the physiological responses of mouse spinal-cord cells to amino acid transmitters have been reported after exposure to GABA and glycine in growth medium (Nelson et al., 1977). We therefore examined the development of neurotransmitter responsiveness in SPNs that were grown in a medium with no added glycine or glutamate (MEM-based medium). If the glycine and glutamate present in the normal (F12-based) neuron medium were causing receptor desensitization in SPNs, then SPNs grown in MEM-based medium would be expected to have larger currents than those normally seen, but this did not happen. At day 4 in vitro, the mean peak current responses $(\mathrm{pA}) \pm$ SEM of SPNs grown in normal medium to GABA, glycine, and glutamate were $593 \pm$ $23,48 \pm 4$, and $26 \pm 2$, respectively, while for cells grown in MEM-based medium the corresponding values were $643 \pm 26$, $27 \pm 6$, and $15 \pm 5$. Because the cells grown in MEM-hased medium had GABA currents, resting membrane potentials, and input resistances that were not statistically different from cells grown in normal neuron medium $(p>0.2)$, this would imply that they were relatively healthy cells. However, these experiments were not carried beyond $4 \mathrm{~d}$ because, by day 7 in vitro, many of the SPNs in MEM-based medium died.

A third possibility, that the cells were expressing receptors for all of the neurotransmitters, but that the binding sites for some were not yet coupled to ion channels, also seems unlikely. If second messengers were involved in any of the responses under study, this question of coupling might have been a concern. However, there is direct molecular evidence that the GABA (Schofield et al., 1987), glycine (Schmeiden et al., 1989), and kainate (Hollman et al., 1989) binding sitcs arc intcgral parts of the ion channels they activate. The extremely rapid activation kinetics of the NMDA and quisqualate responses make it seem likely that the binding site and ion channel will be part of a single molecule for these receptors, as well.

It also seemed possible that the late appearance of NMDA responses might be due to the absence of glycine in the recording solution. Johnson and Ascher (1987) showed that glycine potentiates NMDA responses, and others suggest that the presence of glycine is required for the activation of NMDA receptors (Kleckner and Dingledine, 1988). Therefore, we performed a series of experiments in which $1 \mu \mathrm{M}$ glycine was added to the external recording solution and to the puffer pipette containing NMDA. However, even with glycine present, glutamate responses were not seen at early times in culture.

Finally, it is possible that receptors for glycine and glutamate are present on some or all SPNs in the intact day-7 chick embryo but that they are localized on processes while GABA receptors are localized mainly on the cell body. During the dissociation of cells for culture, most of the cell processes are removed. Therefore, SPNs in culture might not be sensitive to the application of glycine and glutamate until new processes were extended and new receptors were inserted into the membrane. Studies using a variety of techniques have suggested that segregation of receptors occurs in mature neurons in vivo (see, e.g., Foster and Fagg, 1984, Triller et al., 1985). Segregation of receptors to different parts of developing neurons grown in dissociated cell culture has been demonstrated on several different cell types (Ransom et al., 1977; Macdonald et al., 1982; O'Brien and Fischbach, 1986c; Trussell and Fischbach, 1987; James and Klein, 1988, Bekkers and Stevens, 1989).

To gain insight into this possibility, we mapped the responses of SPNs to iontophoretic applications of GABA. For better visualization of the processes, we added 6-carboxyfluorescein $(0.5 \%)$ to the internal solution. The fluorescent dye filled the cell body and most of the dendritic tree of a cell within 3-5 min of obtaining the whole-cell configuration of patch clamping. We tested small discrete areas of the cell for responsiveness to the iontophoretic application of GABA (50-nA, 5-msec pulses of 1 $\mathrm{M}$ GABA at $\mathrm{pH} 7.0$ ). Figure 9 is a tracing of 1 of the 20 neurons studied. On this particular cell, we obtained GABA current records from 30 different spots on the cell surface. We found that there were, indeed, discrete areas of increased GABA responsiveness on both the cell body and the processes of the SPN. The numbers on the figure indicate the location of application of GABA, and the corresponding current responses are shown around the border of the figure. All of these traces are drawn to the same scale. We were able to obtain responses from all parts of the cell surface. Figure 9 , trace 1, shows a relatively small current recorded when GABA was applied to point 1 on the cell body. This current was smaller than several recorded when GABA was applied to the processes. Traces 4 and 5 show currents recorded when GABA was applied to sites that were only a few $\mu \mathrm{m}$ apart. There was a large difference in these currents, indicating discrete patches of high GABA responsiveness. Traces 6 and 7 also correspond to points a few micrometers apart. Point 6 was on a process, and point 7 was a few micrometers lateral to the process. No current is seen in trace 7. This was not due to desensitization because we could apply GABA repetitively to sensitive spots and obtain identical or nearly identical current responses. The fact that no current is seen in trace 7 thus implies that GABA really was applied to discrete areas of the membrane. The largest current recorded on this particular cell occurred when GABA was applied to the cell body, but in 8 of the other cells we tested, the largest current was recorded when GABA was applied to a process. From these studies, it seems that, though there are discrete "hot spots" of GABA responsiveness on SPNs in vitro, they are not preferentially located on either the cell body or the processes. 


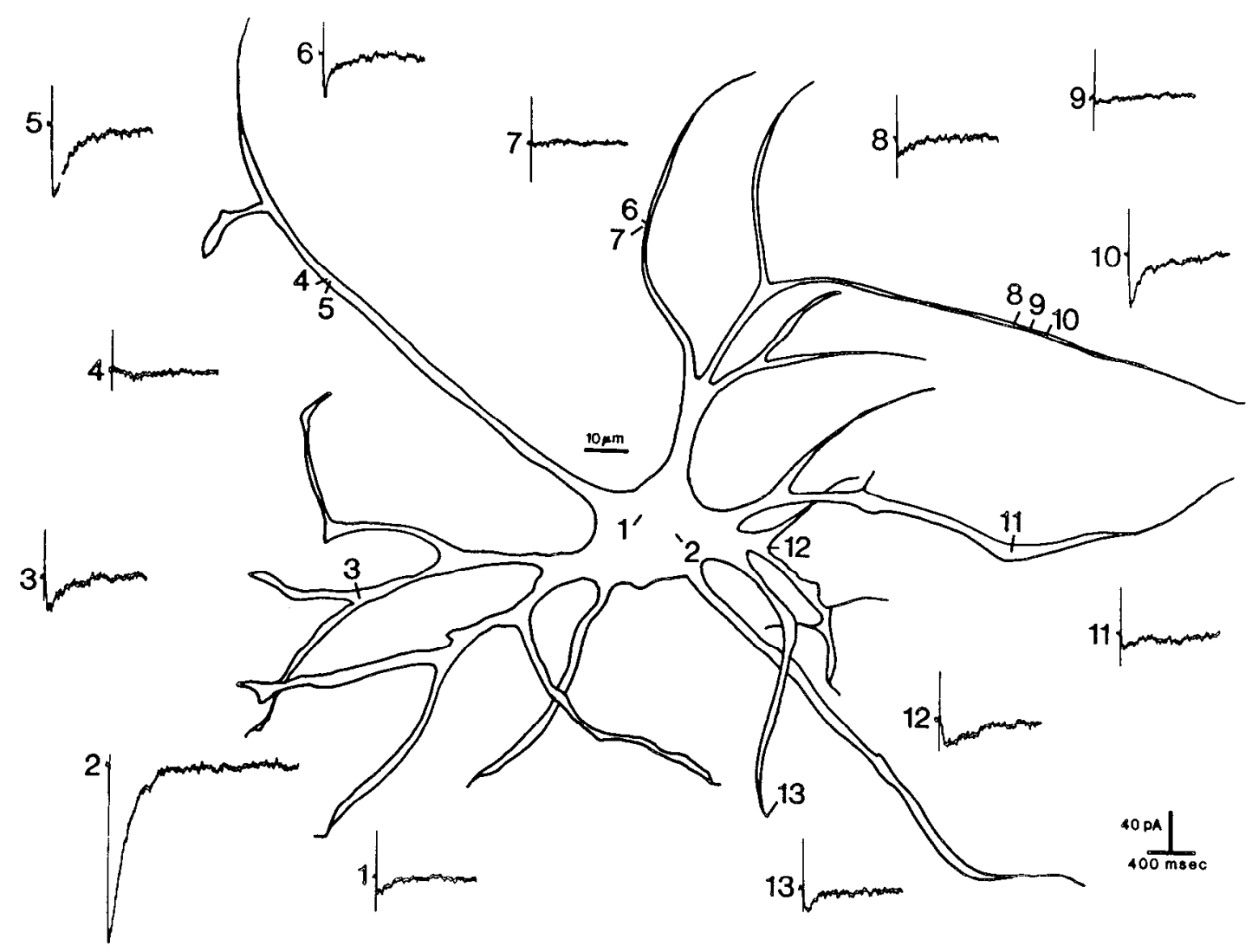

Figure 9. Localization of sites of high GABA responsiveness on cell body and processes of SPN. This figure shows a tracing of a day-6 SPN filled with 6-carboxyfluorescein $(0.5 \%)$ for better visualization of the processes. The numbers around the cell indicate the location of iontophoretic applications of GABA, and the corresponding current responses are shown around the border of the figure. The traces represent whole-cell current responses of this SPN to 5-msec, 50-nA iontophoretic applications of $1 \mathrm{M} \mathrm{GABA}$ at $\mathrm{pH} 7.0$. The cell was held at $-45 \mathrm{mV}$. All of these traces are drawn to the same scale.

We tried to do the same type of iontophoretic mapping experiments with glycine, glutamate, and kainate, using iontophoretic currents as large as $100 \mathrm{nA}$ and pulse lengths as long as $25 \mathrm{msec}$. We were not able to record responses to the discrete application of any of these substances. One possible explanation for this is that receptors to these substances are diffusely scattered on the cell surface and that each iontophoretic application activated so few channels that the responses were below the level of detection. At the other extreme, the receptors to these substances may be so highly localized that the chance of finding these hot spots was very low. In either case, these results suggest that, in culture, glycine and glutamate receptors may have a different distribution on the cell surface than do GABA receptors. It is also important to remember that receptors may be distributed differently in vivo than they are in vitro.

In conclusion, the observation that SPNs become responsive to GABA, glycine, and the 3 glutamate-receptor-specific agonists at distinct times in vitro suggests that receptors to these neurotransmitters are regulated independently. The most striking observation was the apparent lack of responsiveness to the glutamate-receptor agonists NMDA and quisqualate until several days postplating. However, we could not eliminate the possibility that SPNs in stage-30-31 embryos had already expressed receptors for these substances, but that the receptors were lost when processes were removed during dissociation. In the paper that follows (Clendening and Hume, 1990), we show that SPNs can develop dendrites without glutamate receptors. It certainly is not unreasonable to consider the possibility that these cells had not yet begun to express glutamate receptors in vivo.

\section{Transmitter responsiveness of individual neurons}

Because of the uncertainties in the interpretation of the timecourse data, we took a second approach to the issue of whether receptors are regulated independently. As noted above, at any given time in vitro, there was a huge amount of cell-to-cell variation in the responsiveness of SPNs to each neurotransmitter. A trivial explanation of this variability is that the cells with low responsiveness were unhealthy. If this were so, or if the responses of SPNs to these neurotransmitters were normally regulated in a coordinate manner, then one would expect that cells low in responsiveness to GABA would also be low in responsiveness to glutamate and glycine. This, however, was not the case. In Figure 10A, the GABA responses of SPNs on day 5-6 in vitro are plotted against the glycine responses of the same cells. In this scatter plot, there is no obvious relationship between GABA and glycine currents between cells. For instance, cells with GABA-activated currents of $-2000 \mathrm{pA}$ had glycineactivated currents ranging from 0 to $-1800 \mathrm{pA}$. Likewise, cells with glycine-activated currents of $-500 \mathrm{pA}$ had GABA-activated currents ranging from -100 to $-2900 \mathrm{pA}$. The scatter plots in Figure 10, $B$ and $C$, show that there also was no obvious relationship between the size of GABA- and glutamate-activated currents or between glutamate- and glycine-activated currents. Regression analysis confirmed the lack of a significant 

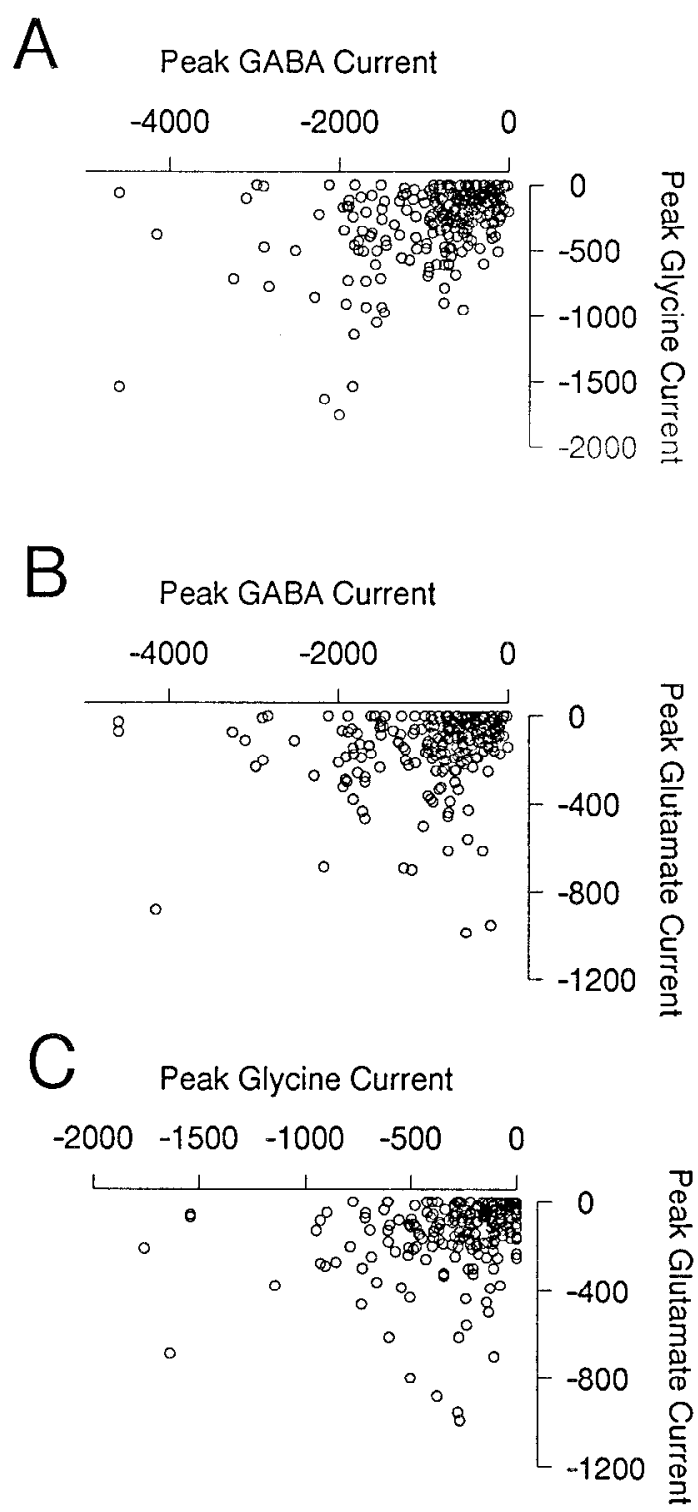

Figure 10. Responses of SPNs to GABA, glutamate, and glycine are not highly correlated. Each panel of this figure is a scatter plot in which the responsiveness of a series of cells to 2 different transmitters is shown. Each point represents the response of a single cell that was held at -45 $\mathrm{mV}$. Transmitters were applied by $500-\mathrm{msec}$ puffs. The concentrations used were $100 \mu \mathrm{M} \operatorname{GABA}(A, B), 50 \mu \mathrm{M}$ glutamate $(B, C)$, and $250 \mu \mathrm{M}$ glycine $(A, C)$. Cells were bathed in $\mathrm{Mg}^{2+}$-free external solution, and normal internal solution was used. Cells were studied 5-6 d after plating. These data were taken from 100 or more cells from more than 10 separate platings.

correlation. Calculated coefficients of determination $\left(r^{2}\right)$ for the best linear fit to the data were 0.18 for GABA and glycine $(n=$ 268), 0.04 for GABA and glutamate $(n=264)$, and 0.08 for glutamate and glycine $(n=248)$. There was also little correlation in the level of responsiveness of SPNs to the subtype-specific glutamate agonists (Fig. 11). The coefficients of determination for the best linear fit to the data were 0.13 for NMDA and kainate $(n=59), 0.06$ for NMDA and quisqualate $(n=53)$, and 0.11 for kainate and quisqualate $(n=53)$.

The lack of a significant correlation between responses to the different transmitters has important ramifications for understanding how multiple receptors are regulated on the surface of
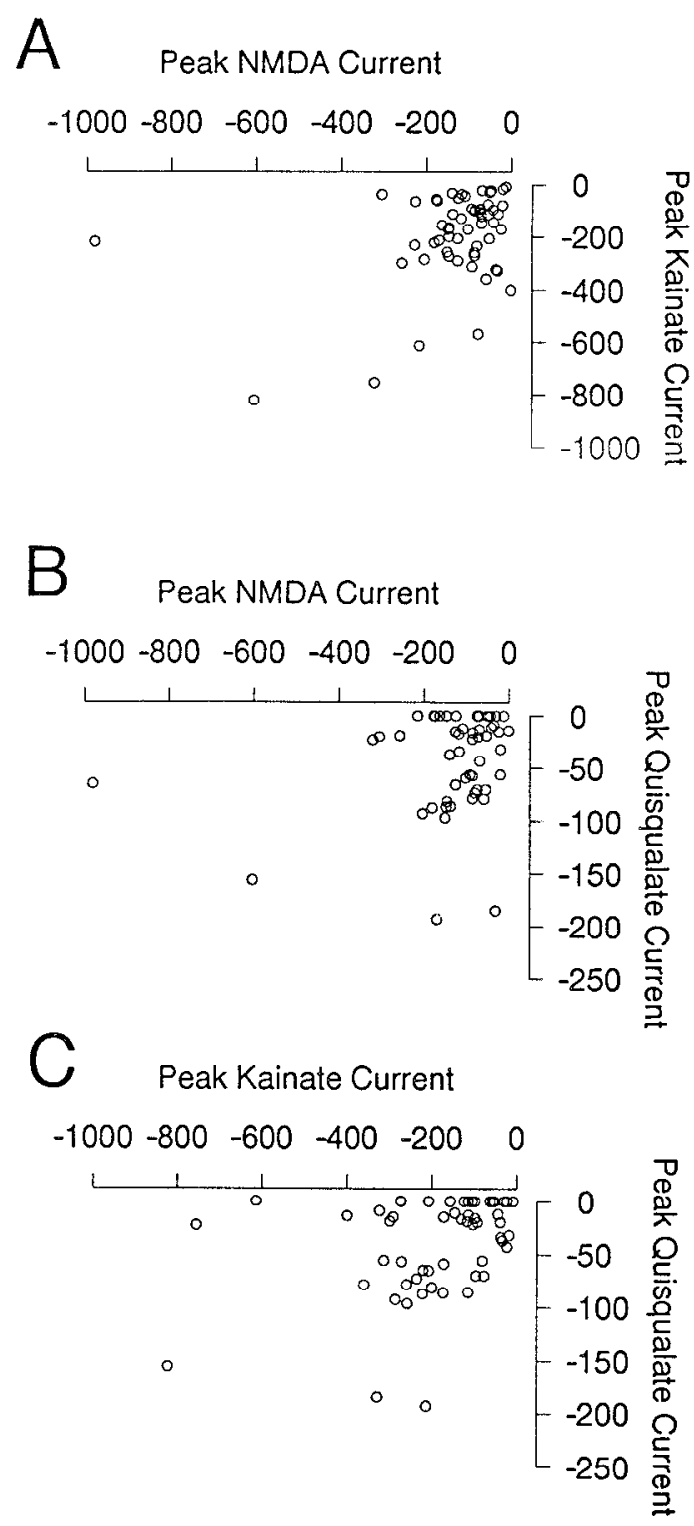

Figure 11. Responses of SPNs to glutamate-receptor subtype-specific agonists are not highly correlated. Each panel of this figure is a scatter plot in which the responsiveness of a series of cells to 2 different agonists is shown. Each point represents the response of a single cell that was held at $-45 \mathrm{mV}$. Agonists were applied by 500 -msec puffs. The concentrations used were $100 \mu \mathrm{M}$ NMDA $(A, B), 100 \mu \mathrm{M}$ kainate $(A, C)$, and $1 \mu \mathrm{M}$ quisqualate $(B, C)$. Cells were bathed in $\mathrm{Mg}^{2+}$-free external solution, and normal internal solution was used. Cells were studied 5$6 \mathrm{~d}$ after plating. These data were taken from 30 or more cells from 3 separate platings.

individual neurons. This result not only seems to rule out the possibility that cells low in responsiveness to one transmitter were "sick" cells, but it strongly suggests that there probably are no global mechanisms that coordinately regulate the expression of these different receptors under our culture conditions. If a global mechanism was operating, some correlation of levels of responsiveness (either positive or negative) should have been revealed in these studies.

\section{Discussion}

By $3-4 \mathrm{~d}$ in culture, most SPNs are scnsitive to the amino acid transmitters GABA, glycine, and glutamate. The physiological 
and pharmacological properties of the responses elicited by each transmitter are consistent with those previously described for GABA, glycine, and glutamate receptors on CNS cells. Previous studies of the neurotransmitter responses of spinal cord neurons in culture have usually examined unidentified cells that have been in culture for 3 or more weeks (Ransom et al., 1977; Macdonald et al., 1982; Mayer and Westbrook, 1985; Vlachova et al., 1987) and thus might be considered to have undergonc a considerable amount of maturation. At the time we place cells into culture (embryonic day 7), they are quite immature. SPNs in the chick are thought to undergo their terminal mitosis during embryonic days 3-5 (Levi-Montalcini, 1950) and to begin to send axons to the periphery at about day 5 (Yip, 1987). The fact that our results are so similar to those of previous studies therefore suggests that the properties of these receptors may not change significantly as cells mature in vitro.

The finding that SPNs are sensitive to multiple neurotransmitters implies that they must deal with the problem of expressing and regulating multiple neurotransmitter receptors. The principal new findings of this study are related to this problem. These findings are that (1) there is an immense amount of cellto-cell variability, even within a single, identified population of CNS cells, in the level of responsiveness to neurotransmitters; (2) though there is a general trend for responsiveness to each neurotransmitter to increase with time in culture, the development of responsiveness to the 3 neurotransmitters follows somewhat different time courses; and (3) there is no detectable correlation between the level of responsiveness of individual neurons to multiple neurotransmitters. Thus, a neuron with high responsiveness to GABA may have low, medium, or high responsiveness to glycine and glutamate. These 3 findings have important ramifications for the way the transmitter responsiveness is regulated in these cells.

The first result makes it unlikely that the variability in transmitter responsiveness that had been seen by others in studies of unidentified CNS neurons (e.g., Ransom et al., 1977; Macdonald et al., 1982) was simply the result of studying a variety of different types of neurons. We studied a single type of CNS neuron and yet found extensive cell-to-cell variability in transmitter responsiveness. Although we cannot rule out the possibility that some of the variability we observed represents differences between subtypes of SPNs (see, e.g., Dodd and Horn, 1983; Horn et al., 1985, 1988), this seems unlikely because the distribution of the response amplitudes for each neurotransmitter appeared to be unimodal. We did not measure the singlechannel conductance of the receptor-associated channels in SPNs; however, by using published values for unitary conductances, one can get an estimate of the minimum number of activated channels necessary to produce the range of responses we saw. In a number of different preparations, glutamate channels have been found to exhibit conductance substates that vary between 6 and $50 \mathrm{pS}$ (O'Brien and Fischbach, 1986b; Cull-Candy and Usowicz, 1987, 1989; Jahr and Stevens, 1987; Vlachova et al., 1987). GABA-channel conductance substates vary from 8 to 44 pS (Choi and Fischbach, 1981; Bormann et al., 1987; Levitan et al., 1988; Weiss et al., 1988; Cull-Candy and Usowicz, 1989; Smith et al., 1989), and glycine activates conductance substates between 17 and 32 pS (Bormann et al., 1987; Smith et al., 1989). If the whole-cell currents we recorded were exclusively due to the smallest classes of single channels reported, then the largest whole-cell currents observed would correspond to fewer than 10,000 open channels. In contrast, if the larger classes of single- channel currents were involved, even the largest whole-cell currents observed would correspond to fewer than 2000 open channels. Because the agonist concentrations used in all of these experiments was that which produced a half-maximal response, it appears that, at most, about 20,000 channels per cell can be activated on the entire cell at this developmental stage. This is quite a small number compared to the $10,000 \mathrm{ACh}$ receptors/ $\mu \mathbf{m}^{2}$ at the mature neuromuscular junctions (Fertuck and Salpeter, 1976).

Concerning the second finding, studies by others have also indicated that transmitter responses can be detected on immature cells, and that receptors can appear at different times. Bixby and Spitzer (1984) have shown that dissociated spinal neurons from early (neural plate stage) Xenopus embryos are initially insensitive to GABA, glycine, and glutamate but that, during the first day in culture, they become sensitive to one or more of these neurotransmitters. Harris and Spitzer (1987) reported that these embryonic spinal-cord cells are first sensitive to GABA on their cell bodies and gradually develop responsiveness along neurites. Similar to our observation that kainate responsiveness appears $2 \mathrm{~d}$ earlier than NMDA responsiveness, Mattson et al. (1988) have recently suggested that cultured rat hippocampal neurons do not develop NMDA responsiveness until several days after they first show kainate responsiveness. The differences in the time courses of appearance of receptors on cultured neurons suggest that the receptors are most likely independently induced both in vivo and in vitro. However, because of the concern that preparing cells for culture may disrupt already-existing receptors (discussed above), definitive studies of the initial expression and localization of receptors will require examination of the intact developing spinal cord.

The electrical measurements that we have made do not directly address the molecular mechanism that leads to the developmental increase in responsiveness to neurotransmitters. Although an increase in the number of receptors for each neurotransmitter might seem to be the most obvious possibility, an increase in some property (unitary conductance, open time, or probability of opening) of the single channels associated with a receptor or a shift in the concentration-response curve could also lead to a significant increase in peak current generated by the binding of neurotransmitters to their respective receptors. Published studies on the developmental properties of $\mathrm{ACh}$ receptors suggest that more than 1 of these changes may occur simultaneously. At the neuromuscular junction, it appears that there is a family of developmentally regulated ACh-receptor molecules with slightly different properties (for review, see Schcutzc and Rolc, 1987). Analysis of the propertics of single channels will be needed to resolve this issue.

The absence of correlation between the responsiveness of individual cells to multiple transmitters seems to rule out the possibility that a global regulatory influence was operating under the culture conditions used. If a global factor regulated multiple receptors, one would have expected to observe some type of correlation (positive or negative) between the levels of responsiveness of SPNs to the different transmitters. The most obvious global factor is the level of spike activity, because spikes can rapidly convey information to all parts of a cell. The evidence is overwhelming that the level of spike activity plays an important role in regulating ACh receptors at the neuromuscular junction (Jones and Vrbova, 1970; Lomo and Rosenthal, 1972; Cohen and Fischbach, 1973; Berg and Hall 1975; Lomo and Westgaard, 1975; Christian et al., 1978; Jessell et al., 1979; 
Steinbach et al., 1979; Reiness and Weinberg, 1981; Brenner and Sakmann, 1983; Usdin and Fischbach, 1986). It is important to remember, however, that muscle has only 1 type of presynaptic input, and therefore, activity is regulating only 1 type of receptor. We did not monitor or control the level of spiking in these experiments, so they do not rule out the possibility that spike activity might regulate 1 of the receptor types that we studied (see Clendening and Hume, 1990). However, the experiments reported here do rule out the possibility that all of the receptors are coordinately regulated by activity. A simple interpretation of the lack of a significant correlation between the pcak responsivencss to the 3 neurotransmitters is that GABA, glycine, and glutamate receptors are regulated independently on SPNs. The observed differences in the time course of appearance of responsiveness to the 3 neurotransmitters also is consistent with this idea.

The different time courses for the development of responsiveness to the 3 glutamate-receptor-subtype agonists and the lack of correlation within cells in their level of responsiveness to these 3 specific agonists suggests that the receptors for these agonists are also regulated independently. This is particularly interesting in light of the recent controversy over how many glutamate-receptor subtypes actually exist. There is good evidence both for the argument that there are separate kainate and quisqualate receptors (Watkins and Evans, 1981; Foster and Fagg, 1984; Vlachova et al., 1987) and for the argument that both agonists activate the same receptor subtype (O'Brien and Fischbach, 1986b; Cull-Candy and Usowicz, 1987; Jahr and Stevens, 1987). Responses to kainate and quisqualate are more likely to be regulated independently if they activate separate receptors than if the 2 agonists bind differently to the same receptor. Our data, therefore, support the argument for separate receptors.

Our results provide several lines of evidence indicating that the receptors for the different neurotransmitters are regulated independently. It clearly would be interesting to know what factors are responsible for this differential regulation. It is striking that responses to glutamate begin to appear at the same time as synaptic currents are first observed in SPNs (3-4 d in vitro). This raises the possibility that it is the process of synapse formation per se that increases the responsiveness of SPNs. Experiments to test several potential mechanisms are reported in the following paper (Clendening and Hume, 1990).

\section{References}

Aprison MH, Daly EC (1978) Biochemical aspects of transmission at inhibitory synapses: the role of glycine. Adv Neurochem 3:203-294.

Aprison MH, Shank RP, Davidoff RA (1969) A comparison of the concentration of glycine, a transmitter suspect, in different areas of the brain and spinal cord of seven different vertebrates. Comp Biochem Physiol 28:1345-1355.

Barker JL, Ransom BR (1978) Amino acid pharmacology of mammalian central neurones grown in tissue culture. J Physiol (Lond) 208: 331-354.

Becker CM, Hoch W, Betz H (1988) Glycine receptor heterogeneity in rat spinal cord during postnatal development. EMBO J 7:37173726.

Bekkers JM, Stevens CF (1989) NMDA and non-NMDA receptors are co-localized at individual excitatory synapses in cultured rat hippocampus. Nature 341:230-233.

Berg DK, Hall ZW (1975) Increased extrajunctional acetylcholine sensitivity produced by chronic post-synaptic neuromuscular blockade. J Physiol (Lond) 244:659-676.
Bixby JL, Spitzer NC (1984) The appearance and development of neurotransmitter sensitivity in Xenopus embryonic spinal neurones in vitro. J Physiol (Lond) 353:143-155.

Bormann J, Hamill OP, Sakmann B (1987) Mechanism of anion permeation through channels gated by glycine and gamma-aminobutyric acid in mouse cultured neurones. J Physiol (Lond) 385:243-286.

Brenner HR, Sakmann B (1983) Neurotrophic control of channel properties at neuromuscular synapses of rat muscle. J Physiol (Lond) 337: 159-171.

Cabot JB, Reiner A, Bogan N (1982) Avian bulbospinal pathways: anterograde and retrograde studies of cells of avian funicular trajectories and laminar terminations. Prog Brain Res 57:79-108.

Choi DW, Fischbach GD (1981) GABA conductance of chick spinal cord and dorsal root ganglion neurons in cell culture. J Neurophysiol 45:605-620.

Christian CN, Daniels MP, Sugiyama H, Vogel Z, Jacques L, Nelson $P G$ (1978) A factor from neurons increases the number of acetylcholine receptor aggregates on cultured muscle cells. Proc Natl Acad Sci USA 8:4011-4015.

Clendening B, Humc RI (1990) Cell interactions regulate dendritic morphology and responses to neurotransmitters in embryonic chick sympathetic preganglionic neurons in vitro. J Neurosci 10:3992-4005.

Cohen SA, Fischbach GD (1973) Regulation of muscle acetylcholine sensitivity by muscle activity in cell culture. Science 181:76-78.

Coote JH, MacLeod VH (1974) The influence of bulbospinal monoaminergic pathways on sympathetic nerve activity. J Physiol (Lond) $241: 453-475$.

Cull-Candy SG, Usowicz M (1987) Multiple-conductance channels activated by excitatory amino acids in cerebellar neurons. Nature 325 : 525-528.

Cull-Candy SG, Usowicz MM (1989) Whole-current noise produced by excitatory and inhibitory amino acids in large cerebellar neurons of the rat. J Physiol (Lond) 415:533-553.

Dahlstrom A, Fuxc K (1965) Evidence for the existence of monoamine neurons in the CNS. II: experimentally induced changes in the intraneural amine levels of bulbospinal neuron systems. Acta Physiol Scand 64 [Suppl 247]:5-36.

Dodd J, Horn JP (1983) A reclassification of B and C neurones in the ninth and tenth paravertebral sympathetic ganglia of the bullfrog. J Physiol (Lond) 334:255-269.

Evans RH, Francis AA, Jones AW, Smith DAS, Watkins JC (1982) The effects of a series of $\gamma$-phosphonic- $\alpha$-carboxylic amino acids on electrically evoked and excitant amino acid-induced responses in isolated spinal cord preparations. $\mathrm{Br} \mathrm{J}$ Pharmacol 75:65-75.

Fagg GE, Foster AC (1983) Amino acid neurotransmitters and their pathways in the mammalian central nervous system. Neuroscience 9:701-719.

Fcrtuck HC, Salpeter MM (1976) Quantitation of junctional and extrajunctional acetylcholine receptors by electron microscope autoradiography after ${ }^{125}$ I-alpha-bungarotoxin binding at mouse neuromuscular junctions. J Cell Biol 69:144-158.

Fleetwood-Walker SM, Coote JH (1981) The contribution of brainstem catecholamine cell groups to the innervation of the sympathetic lateral cell column. Brain Res 205:141-155.

Foster AC, Fagg GE (1984) Acidic amino acid sites in mammalian neuronal membrane: their characteristics and relationship to synaptic receptors. Brain Res Rev 7:103-164.

Gilbey MP, Coote JH, Macleod VH, Peterson DF (1981) Inhibition of sympathetic activity by stimulating in raphe nuclei and the role of 5-hydroxytryptamine in this effect. Brain Res 226:131-142.

Glazer EJ, Ross LL (1980) Localization of noradrenergic terminals in sympathetic preganglionic nuclci of the rat: demonstration by immunocytochemical localization of dopamine hydroxylase. Brain Res 185:39-49.

Graham LT, Shank RP, Werman R, Aprison MH (1967) Distribution of some synaptic transmitter suspects in cat spinal cord: glutamic acid, GABA, glycine and glutamine. J Neurochem 14:465-472.

Hamill OP, Marty A, Neher E, Sakmann B, Sigworth FJ (1981) Improved patch-clamp techniques for high-resolution current recordings from cells and cell-free membrane patches. Pfluegers Arch 351:85100.

Harris GL, Spitzer NC (1987) Spatial distribution of GABA receptors at the time of their appearance on spinal neurons differentiating in culture. Soc Neurosci Abstr 13:150. 
Hollman M, O'Shea-Greenfield A, Rogers SW, Heinemann S (1989) Cloning by functional expression of a member of the glutamate receptor family. Nature 342:643-648.

Honig MG, Hume RI (1986) Fluorescent carbocyanine dye allows living neurons of identified origin to be studied in long-term cultures. J Cell Biol 103:171-187.

Horn JP, Stofer WD, Fatherazi S (1985) Identified subclasses of bullfrog sympathetic neurons project to different types of peripheral targets. Soc Neurosci Abstr 11:64.

Horn JP, Fatherazi S, Stofer WD (1988) Differential projections of B and $C$ sympathetic axons in peripheral nerves of the bullfrog. J Comp Neurol 278:570-580.

Jahr CE, Stevens CF (1987) Glutamate activates multiple single channel conductances in hippocampal neurons. Nature 325:522-525.

James WM, Klein WL (1988) Localization of acetylcholine receptors on isolated CNS neurons: cellular and subcellular differentiation. J Neurosci 8:4225-4238.

Jessell TM, Siegel RE, Fischbach GD (1979) Induction of acetylcholine receptors on cultured skeletal muscle by a factor extracted from brain and spinal cord. Proc Natl Acad Sci USA 10:5397-5401.

Johnson JW, Ascher P (1987) Glycine potentiates the NMDA response in cultured mouse brain neurons. Nature 325:529-531.

Jones R, Vrbova G (1970) Effect of muscle activity on denervation hypersensitivity. J Physiol (Lond) 210:144-145P.

Kiskin NI, Krishtal OA, Tsyndrenko AY (1986) Excitatory amino acid receptors in hippocampal neurons: kainate fails to desensitize them. Neurosci Lett 63:225-230.

Kleckner NW, Dingledine R (1988) Requirements for glycine in activation of NMDA-receptors expressed in Xenopus oocytes. Science 241:835-837.

Kruskal WH, Wallis WA (1952) Use of ranks in one-criterion variance analysis. J Am Stat Assoc 47:583-621.

Levi-Montalcini R (1950) The origin and development of the visceral system in the spinal cord of the chick embryo. J. Morphol 86:253283.

Levitan ES, Blair LA, Dionne VE, Barnard EA (1988) Biophysical and pharmacological properties of cloned $\mathrm{GABA}_{\mathrm{A}}$ receptor subunits expressed in Xenopus oocytes. Neuron 1:773-781.

Ljungdahl A, Hokfelt T (1973) Autoradiographic uptake patterns of ${ }^{3} \mathrm{H}-\mathrm{GABA}$ and ${ }^{3} \mathrm{H}$-glycine in central nervous system tissue with special reference to the cat spinal cord. Brain Res 15:185-200.

Loewy AD, McKellar S (1981) Serotonergic projections from the ventral medulla to the intermediolateral cell column in the rat. Brain Res 211:146-152.

Loewy, AD, McKellar S, Saper CB (1979) Direct projections from the A5 catecholamine cell group to the intermediolateral cell column. Brain Res 174:309-314.

Lomo T, Rosenthal J (1972) Control of ACh sensitivity by muscle activity in the rat. $J$ Physiol (Lond) 221:492-513.

Lomo T, Westgaard RH (1975) Further studies on the control of ACh sensitivity by muscle activity in the rat. J Physiol (Lond) 252:603626.

Macdonald RL, Moonen G, Neale EA, Nelson PG (1982) Cerebellar macroneurons in microexplant cell culture. Postsynaptic amino acid pharmacology. Dev Brain Res 5:75-88.

Mattson MP, Dou P, Kater SB (1988) Outgrowth-regulating actions of glutamate in isolated hippocampal pyramidal neurons. J Neurosci 8:2087-2100.

Mayer ML, Westbrook GL (1985) The action of $N$-methyl-D aspartic acid on mouse spinal neurones in culture. J Physiol (Lond) 361:6590.

Mayer ML, Westbrook GL, Guthrie PB (1984) Voltage-dependent block by $\mathrm{Mg}^{2+}$ of NMDA responses in spinal cord neurones. Nature 309:261-263.

Monaghan DT, Bridges RJ, Cotman CW (1989) The excitatory amino acid receptors: their classes, pharmacology and distinct properties in the function of the central nervous system. Annu Rev Pharmacol Toxicol 29:365-402.

Nelson PG, Ransom BR, Henkart M, Bullock PN (1977) Mouse spinal cord in cell culture. IV. Modulation of inhibitory synaptic function. J Neurophysiol 40:1178-1187.
Nowak L, Young AB, Macdonald RL (1982) GABA and bicuculline actions on mouse spinal cord and cortical neurones in cell culture. Brain Res 244:155-164.

Nowak L, Bregestovski P, Ascher P (1984) Magnesium gates glutamate-activated channels in mouse central neurones. Nature 307:462465.

O'Brien RJ, Fischbach GD (1986a) Isolation of embryonic chick motoneurons and their survival in vitro. J Neurosci 6:3265-3274.

O'Brien RJ, Fischbach GD (1986b) Characterization of excitatory amino acid receptors expressed by embryonic chick motoneurons in vitro. J Neurosci 6:3275-3283.

O'Brien RJ, Fischbach GD (1986c) Modulation of embryonic chick motoneuron glutamate sensitivity by interneurons and agonists. $J$ Neurosci 6:3290-3296.

Okun LM (1981) Identification and isolation in vitro of neurons marked in situ by retrograde transport. In: New approaches in developmental neurobiology, pp 109-121. Washington, DC: Society for Neuroscience.

Pfeiffer F, Graham D, Betz H (1982) Purification by affinity chromatography of the glycine receptor of rat spinal cord. J Biol Chem 257:9389-9393.

Ransom BR, Bullock PN, Nelson PG (1977) Mouse spinal cord in cell culture. III. Neuronal chemosensitivity and its relationship to synaptic activity. J Neurophysiol 40:1163-1177.

Reiness CG, Weinberg CB (1981) Metabolic stabilization of acetylcholine receptors at newly formed neuromuscular junction in rat. Dev Biol 84:247-254.

Scheutze SM, Role LW (1987) Developmental regulation of nicotinic acetylcholine receptors. Annu Rev Neurosci 10:403-457.

Schmeiden S, Grenningloh G, Schofield PR, Betz H (1989) Functional expression in Xenopus oocytes of the strychnine binding $48 \mathrm{kd}$ subunit of the glycine receptor. EMBO J 8:695-700.

Schofield PR, Darlison MG, Fujita N, Burt DR, Stephenson FA, Rodriguez H, Rhee LM, Ramachandran J, Reale V, Glencorse TA, Seeburg PH, Barnard EA (1987) Sequence and functional expression of the $\mathrm{GABA}_{\mathrm{A}}$ receptor shows a ligand-gated receptor super-family. Nature 328:221-227.

Segal M, Barker JL (1984) Rat hippocampal neurons in culture: properties of GABA-activated $\mathrm{Cl}^{-}$ion conductance. J Neurophysiol 52: 469-487.

Smith SM, Zorec R, McBurney RN (1989) Conductance states activated by glycine and GABA in rat cultured spinal neurones. J Membr Biol 108:45-52.

Steinbach JH, Merlie J, Heinemann S, Bloch R (1979) Degradation of junctional and extrajunctional acetylcholine receptors by developing rat skeletal muscle. Proc Natl Acad Sci USA 76:3547-3551.

Triller A, Cluzeaud F, Pfeiffer F, Betz H, Korn H (1985) Distribution of receptors at central synapses: an immunoelectron microscopy study. J Cell Biol 101:683-688.

Trussell LO, Fischbach GD (1987) Iontophoretic mapping of glutamate receptors on cultured chick spinal neurons. Soc. Neurosci Abstr 13:384.

Trussell LO, Thio LL, Zorumski CF, Fischbach GD (1988) Rapid desensitization of glutamate receptors in vertebrate central neurons. Proc Natl Acad Sci USA 85:2834-2838.

Usdin TB, Fischbach GD (1986) Purification and characterization of a polypeptide from chick brain that promotes the accumulation of acetylcholine receptors in chick myotubes. J Cell Biol 103:493-507.

Vlachova V, Vyklicky L, Vyklicky L, Jr, Vyskocil F (1987) The action of excitatory amino acids on chick spinal cord neurones in culture. $J$ Physiol (Lond) 386:425-438.

Watkins JC, Evans RH (1981) Excitatory amino acid transmitters. Annu Rev Pharmacol Toxicol 21:165-204.

Weiss DS, Barnes EM, Hablitz JJ (1988) Whole-cell and single-channel recordings of GABA-gated currents in cultured chick cerebral neurons. J Neurophysiol 59:495-513.

Yip JW (1987) Target cues are not required for the guidance of sympathetic preganglionic axons. Dev Brain Res 32:155-159. 